\title{
A Preliminary Study of Meteorological Drought Influences to Social Events over the Maritime Continent during The Last Millennium
}

\author{
Sandy Hardian Susanto Herho \\ Department of Meteorology, Bandung Institute of Technology, Bandung, Indonesia \\ Muhammad Ridho Syahputra \\ Department of Meteorology, Bandung Institute of Technology, Bandung, Indonesia \\ Rusmawan Suwarman \\ Department of Meteorology, Bandung Institute of Technology, Bandung, Indonesia
}

\begin{abstract}
Drought is a climate phenomenon that greatly impacts the social conditions of the Southeast Asian throughout the history. This study used HadCM3 output in PMIP3 Last Millennium Simulations to analyze the influences of climate variabilities to various changes in meteorological drought. Using SPI-12 they categorized as moderate and severe \& extreme drought, The impact of the drought then carried out on the conditions of political history in Southeast Asia. The worst drought conditions over the Maritime Continent occurred in mid-14th until the middle of the 15th century and the mid-18th until the mid-19th century. PDO and ENSO as the major climate variabilities modulates drought over the Maritime Continent during the Last Millennium period. Severe \& extreme drought over the Maritime Continent is also considered influencing the political history of Southeast Asia during the Last Millennium period, especially in agrarian societies.
\end{abstract}

\section{Introduction}

Social conditions throughout humankind history are always directly affected by climate change (Gupta 2004). Humans respond to this climate change by adapting and migrating. Archaeological findings shows that humans are able to adapt the extreme cold of Arctic and dry climates of Thar and the Sahara Desert during the Late Pleistocene-about 27,000 years ago- (Dow et al. 2005). Nonetheless some civilizations actually collapsed due to climate change. Extreme drought with long time scales are the driving force behind the collapse of the world's great civilizations, among others : Akkadian Civilizations, Maya, Mochica, Tiwanaku and Anasazi (deMenocal 2001). Extreme drought can last up to decades at erratic intervals (Cook et al. 2010). Drought plays an important role in the socio-historical context in Asia, i.e. the collapse of Yuan Dynasty (Zhang et al. 2008) and Ming Dynasty (Shen et al. 2007) in China; and the Khmer Kingdom in Cambodia (Buckley et al. 2010).

${ }^{*}$ Corresponding author address: Sandy H. S. Herho, Bandung Institute of Technology, Dept. of Meteorology, Bandung, Indonesia 40132, e-mail: sandyherho@meteo.itb.ac.id
The Maritime Continent is defined as a group of islands in the western Pacific Ocean, comprising the territory of Indonesia, and Southeast Asia Islands located between $10^{\circ} \mathrm{N}-10^{\circ} \mathrm{S}$ (Ramage 1968). The Maritime Continent in general is also a region of the monsoon circulation, which is the global atmospheric circulation throughout the tropics that changes direction -back and forth- on a seasonal time scale (Trenberth et al. 2000). The Southeast Asian Archipelago is affected by two monsoon systems, the Asian monsoon and the Australian monsoon and a transitional region between both monsoons (Chang et al. 2004). In addition to the monsoons, the climate of the Maritime Continent is also influenced by the El Niño Southern Oscillation (ENSO), which is also undergoing long-term changes affected by long-term climate variability in the Pacific Decadal Oscillation (PDO) (Newman et al. 2003).

The Maritime Continent known as a region prone to natural disasters throughout the years (Wardani and Kodoatie 2008), hence it is necessary to anticipate the impact of this 
drought on the community. Initial step to anticipate drought impacts over the Maritime Continent region is understanding the specific long-term meteorological drought (intensity, number of droughts, and teleconnection with climate variability) and their impact on socio-political conditions over the course of history.

The global climate model is one of the most important efforts in improving understanding and the predictability of a climate phenomenon, one of which is drought. Global climate models in the Last Millennium Simulations PMIP3/CMIP5 project are able to analyze the intensity of historical drought phenomena in Asia and Southeast Asia (Fallah and Cusbach 2015).

In this study, drought analysis was conducted using the HadCM3 output over the Maritime Continent region during the Last Millennium period (850 - $1850 \mathrm{CE}$ ), in order to maximize the global climate model's potential output enabling the spatial and temporal variation overview of meteorological droughts in longer climate time scales and their effects to the political history of Southeast Asia.

\section{Data and Results}

The HadCM3 output in PMIP3 Last Millennium Simulations has never been used to analyze the climate of the Last Millennium over the Maritime Continent, therefore comparisons to recent climate conditions are required. The dominant climate phenomenon over the Maritime Continent is the monsoon (Robertson et al. 2011). Assuming that there is no significant difference between the Asian Monsoon pattern of the Last Millennium and the recent monsoon condition (Clift and Plumb 2008), a comparative visual comparison of seasonal rainfall and seasonal wind composite December to January (DJF) and June to August (JJA) - every 100 years of model output with recent composite reanalysis data of rainfall and seasonal surface wind (Fig. 1). Last Millennium monthly rainfall and surface wind data from HadCM3 ensemble r1i1p1 with the spatial resolution of $3.75^{\circ} \times 2.5^{\circ}$ is obtained from ESGF (Schurer et al. 2013). Recent monthly rainfall and surface wind data obtained from NCEP-DOE AMIP-II REANALYSIS (R-2) with the spatial resolution of $2.5^{\circ} \times 2.5^{\circ}$ (Kanamitsu et al. 2002). Visually, there is no significant difference between seasonal rainfall and seasonal wind patterns over the Maritime Continent at Last Millennium with seasonal recent climatological conditions. However, as shown in Fig. 1 and DR1, the Maritime Continent experiences wetter condition in the Last Millennium, compared to recent condition. Reinforced by the reconstruction of the 1,400-years-old lacustrine sediment proxy on the island of Java proves that Java is getting wetter. (Rodysill et al. 2012; Konecky et al. 2013). Yoden et al. (2017) also state that the Last Millennium Intertropical Convergence Zone (ITCZ) migration moving over the Maritime Continent to the south causing intensification of rainfall in Java Island in the last two centuries. The intensification of rainfall is corroborated by the output of the HadCM3 model on Last Millennium. By comparing these two monsoon parameters on a seasonal basis, the output of the HadCM3 model on Last Millennium can be used to analyze meteorological droughts over the Maritime Continent. 
a

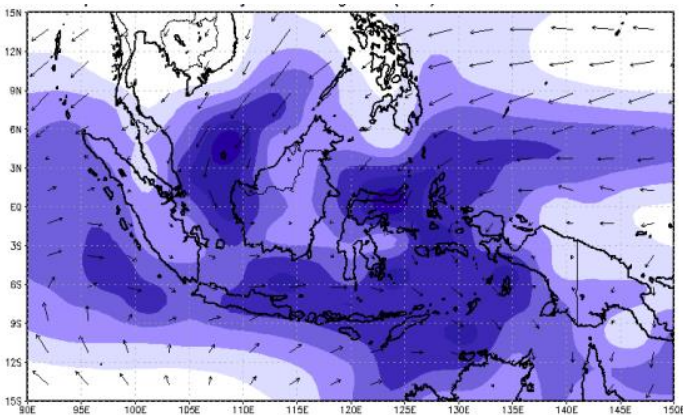

b

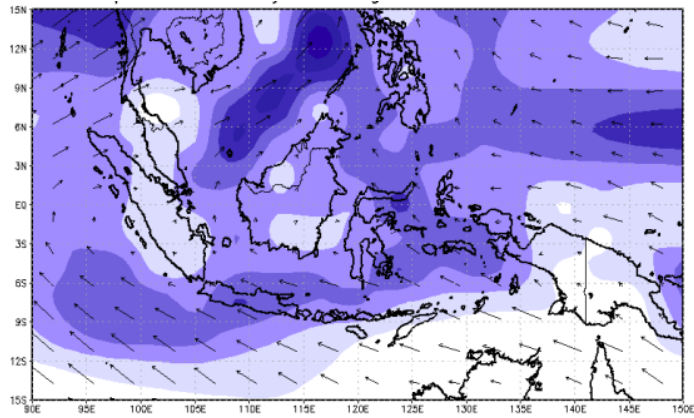

C

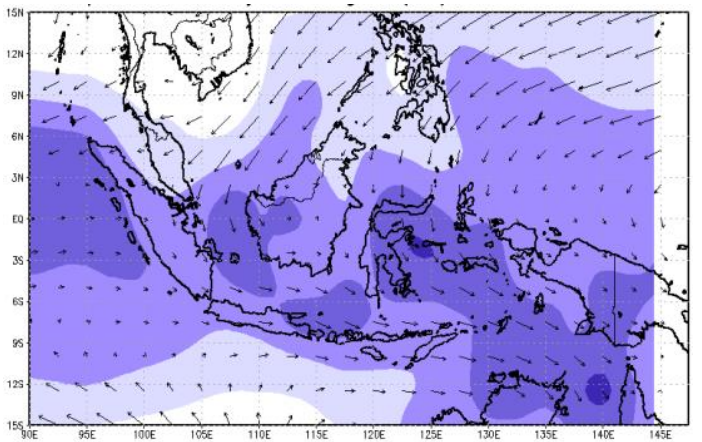

d

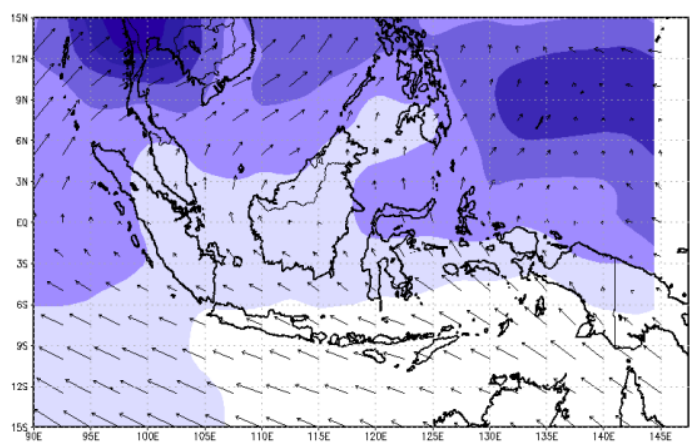

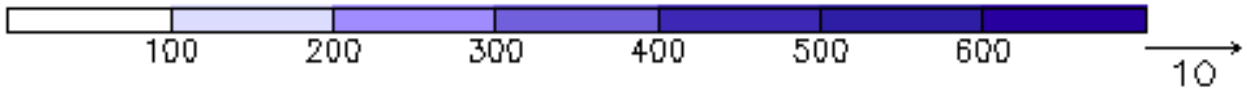

FIG.1. Comparison of contour maps of HadCM3 r1i1p1 Last Millennium simulation for one of the century in 850- 1850 CE (1750-1850 CE) (a-b) and NCEP/NCAR reanalysis for the period 1979-2016 CE (c-d), composite means of surface precipitation in mm month-1 with arrows denoting near surface wind direction in m s-1 for wet season (DJF, left) and dry season (JJA, right).

The meteorological drought in this study using the Standardized Precipitation Index (SPI) (McKee et al. 1993), as it is considered the best meteorological drought index (Zargar et al. 2011) and monthly SPI-12 which considered capable of reflecting longterm rainfall patterns (Zargar et al. 2011). Monthly SPI-12 for each Maritime Continent's grid is calculated from the monthly rainfall data from 850 to $1850 \mathrm{CE}$, with removed first year. The drought characteristics we use to analyze spatial and temporal variations are the anomalies of the area of drought and the frequency of occurrence. The monthly SPI-12 data for moderate drought $(-1 \geq \mathrm{SPI}-12>-1,5)$ and severe \& extreme $(\mathrm{SPI}-12 \leq-1,5)$ categories over the Maritime Continent region from 851 $-1850 \mathrm{CE}$ on the land grid are the inputs in calculating the area of drought (Wilhite 2003) for each category over the duration of the data. The time series anomalies data of the drought area serves as a basis for temporal drought analysis over the Maritime Continent.

By calculating and classifying the monthly SPI-12 values on the rainfall data from the HadCM3 model on each terrestrial land grid, we obtain drought categorized maps for every 100 years in the $851-1850$ CE period. The frequency of drought occurrence anomalies is calculated based on the number of occurrences of each grid in each drought value category which is then reduced by the average of drought occurrence over the period of data, then divided against the number of months in 100 years. Spatially, the greatest extent of drought occurrence for each categories throughout Last Millennium, according to the output of the HadCM3 model, occurred in 1751-1850 CE (Fig. 2). This period is also noted as one of the most parched period in Java $(1790-1800$ and $1840-1900$ CE) based on the rainfall intensity reconstruction carried out by Konecky et al. (2013). The 
frequency of drought occurrence anomalies in other centuries are shown in DR2.
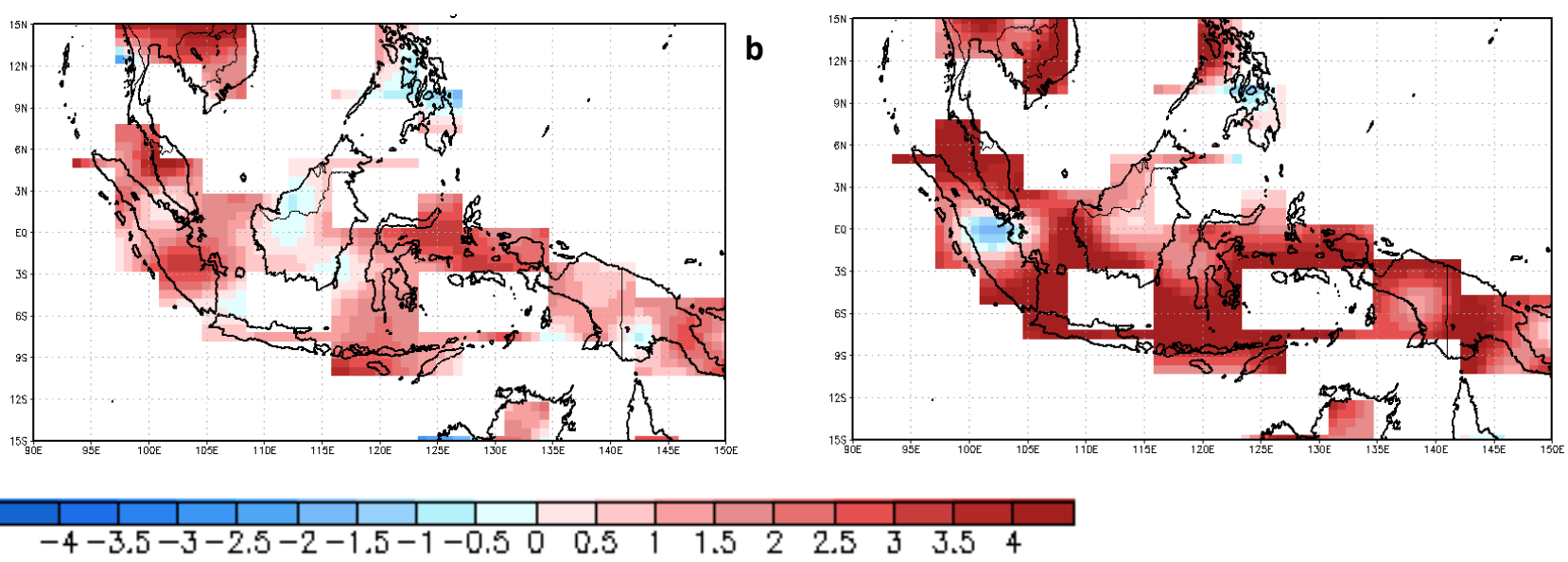

FIG. 2. Drought severity maps categorized (a) moderate and (b) severe \& extreme drought based on the anomaly of meteorological drought frequency of occurrence during the most severe drought episode over the Maritime Continent in 1751-1850 CE.

The anomalies of the drought area are calculated using SPI-12 data in each category on each land grid. The drought area data furthermore reduced by the average area of drought data throughout the data period and normalized, resulting drought anomalous time series data on the categories(Fig.3). Anomalous drought area over the Maritime Continent shows an increasing trend of the anomalous amount of area experiencing drought from 851 to 1850 CE. Based on the result of anomalous calculation of drought area in Fig. 3, there is a dominant mode shift with 500 year cycle periodicity in the mid-14th century. In the beginning of the Last Millennium period (850 $-1350 \mathrm{CE})$, the anomalous conditions of the drought area are dominated by wet anomalies, whereas at the end of the Last
Millennium is quite the opposite. The anomalous drought conditions are dominated by dry modes culminating in the mid-18th and 19th centuries. This 500-year drought mode change also appears in Fast Fourier Transforms (FFT), assuming anomalous data of drought area as a stationary data (Fig.4). Through Continuous Wavelet Transforms (CWT) - assuming nonstationary data - it is also found that at the shift of the 14th Century to the 15th century. The dominant mode of dominant drought occurrence occurred with periodicity over 256 ye ar cycle (Fig.5). This change in drought mode is suspected as a result of the ITCZ shift in the mid of the Last Millennium in response to inter-hemispheric heat gradient changes in the $1300 \mathrm{~s}$ CE that marked the end of the Medieval Warm Period (MWP) and the beginning of the Little Ice Age (LIA) (Newton et al., 2006). 
a

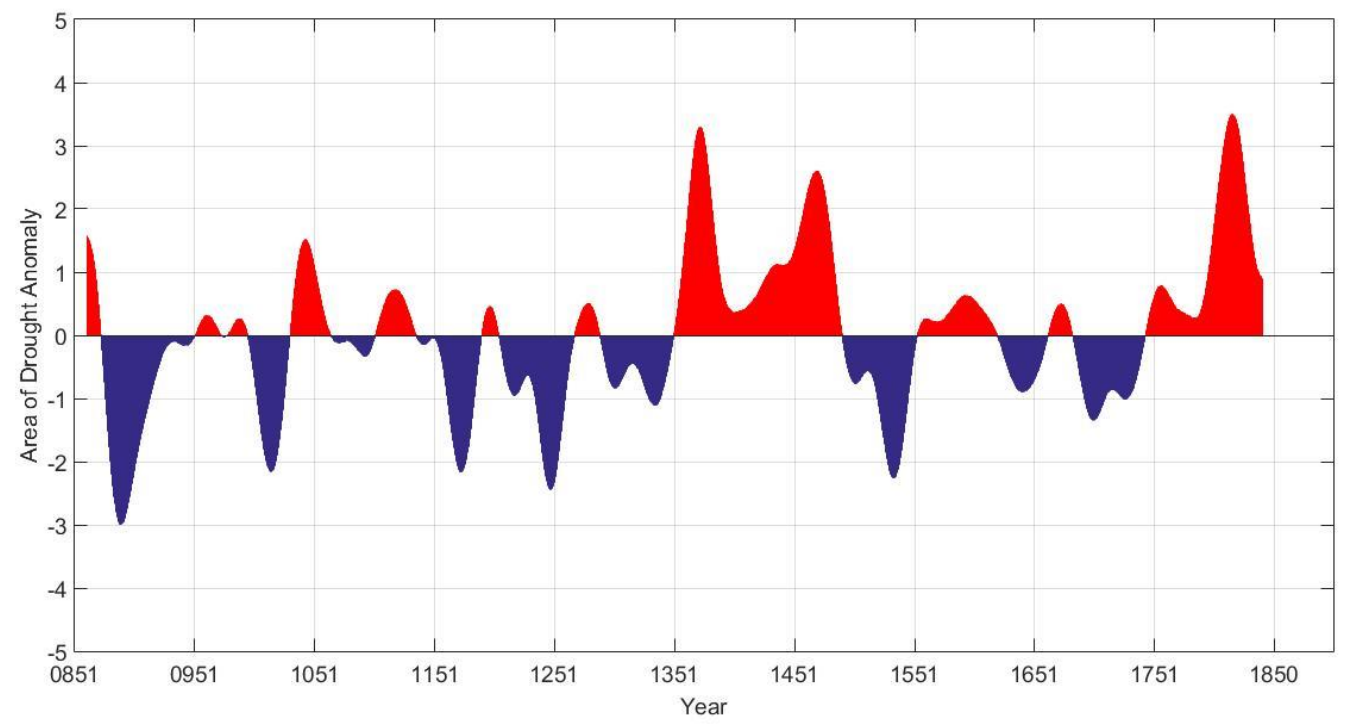

b

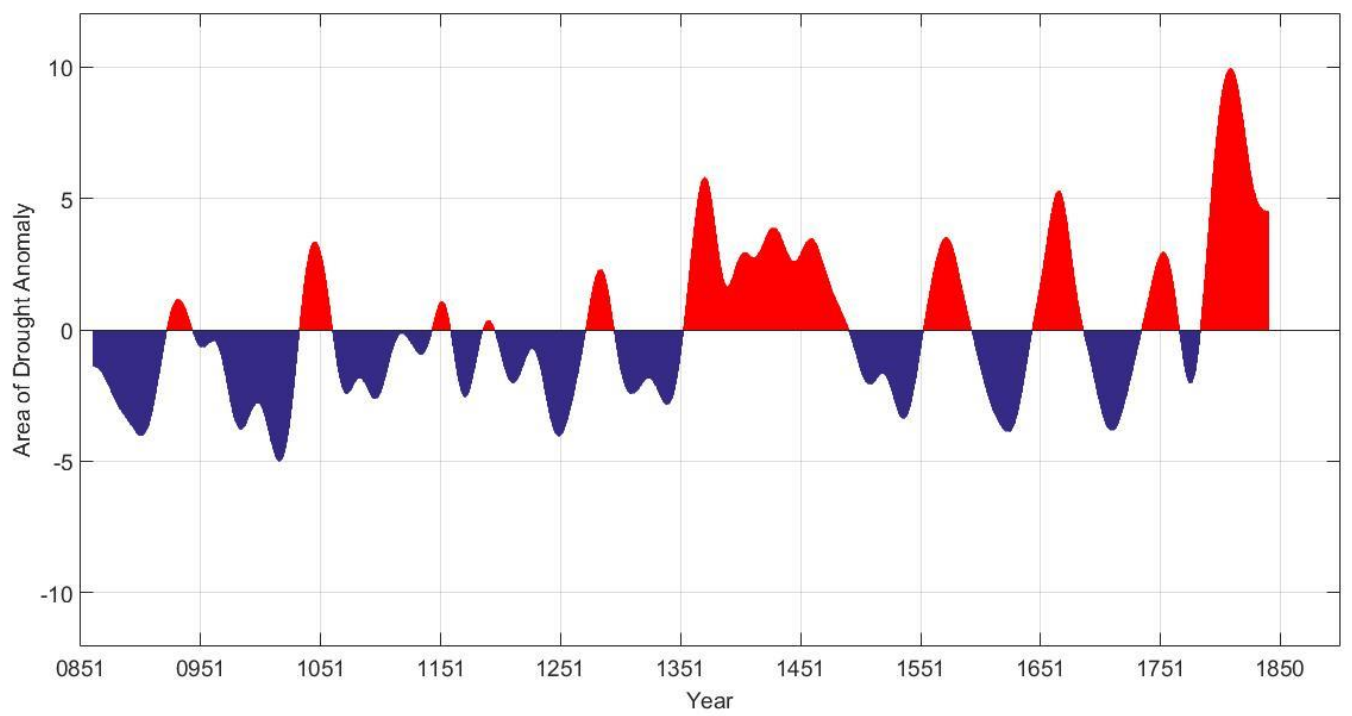

FIG. 3. The normalized area of drought anomaly time series in the Last Millennium categorized: (a) moderate and (b) severe \& extreme drought.

In addition to the 500-year cycle mode that dominates the area of drought anomalies over the Maritime Continent, there are also variations of the anomalous mode of drought extent with interdecadal, quasi-centennial, to centennial timescales. This is shown in FFT (Fig.4) and CWT (Fig.5). In FFT, it is known that the anomalous area of drought over the Maritime Continent is strongest in succession at a period of $89.09 ; 500 ; 122.5$; 108.9 ; 75,38 ; and 40.38 year cycle. In the
CWT, it is known that the anomalous variation of the drought extent on the interdecadal time scale (dominant over most periods of data, with a periodicity of about 16-32 years) is thought to be due to the dominant ENSO phenomenon on the interdecadal scale on Last Millennium as multiproxy records done by Li et al. (2013). While the variation of drought area anomalies on the quasi-centennial time scale, to centennial (dominant in the anomalous period of ca. 1500-1800 CE drought with $64-128$ year cycle periodicity) 
is thought to be due to the dominant climate variability in PDO's in multidecadal mode (50-70 year cycle) and quasi-centennial (75
- 115 year cycle) such as the PDO index reconstruction done by Shen et al. (2006) in the years $1470-2000 \mathrm{CE}$.

a

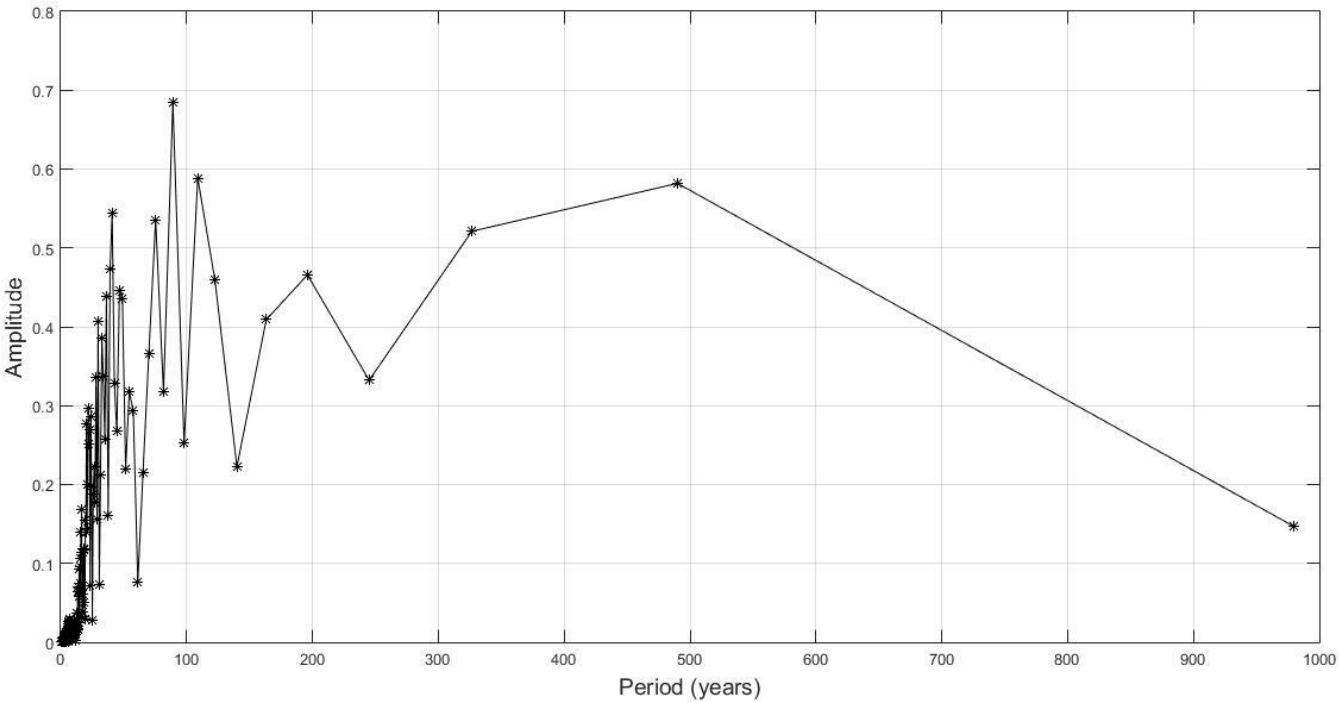

b

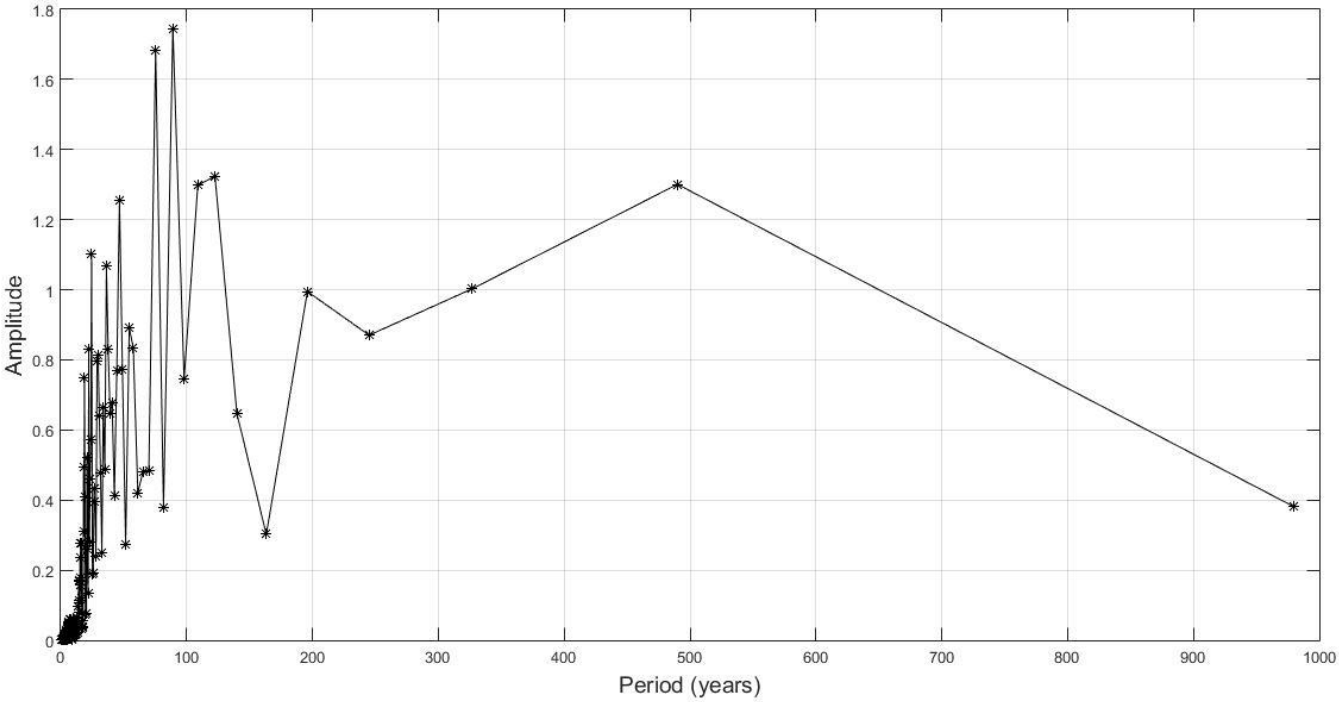

FIG. 4. The spectrum of the area of drought anomaly time series using a FFT with the $95 \%$ confidence limits at the spectral peaks categorized: (a) moderate and (b) severe \& extreme drought.

To determine the influences of ENSO and PDO on drought over the Maritime Continent, we reconstructed the ENSO and PDO indices using the global sea surface temperature (SST) data from the HadCM3 Last Millennium Simulation output in the Pacific Ocean. Data obtained from ESGF with a spatial resolution of $1.25^{\circ} \times 1.25^{\circ}$ (Schurer et al. 2013). Data used from 850 to 1850 CE. 


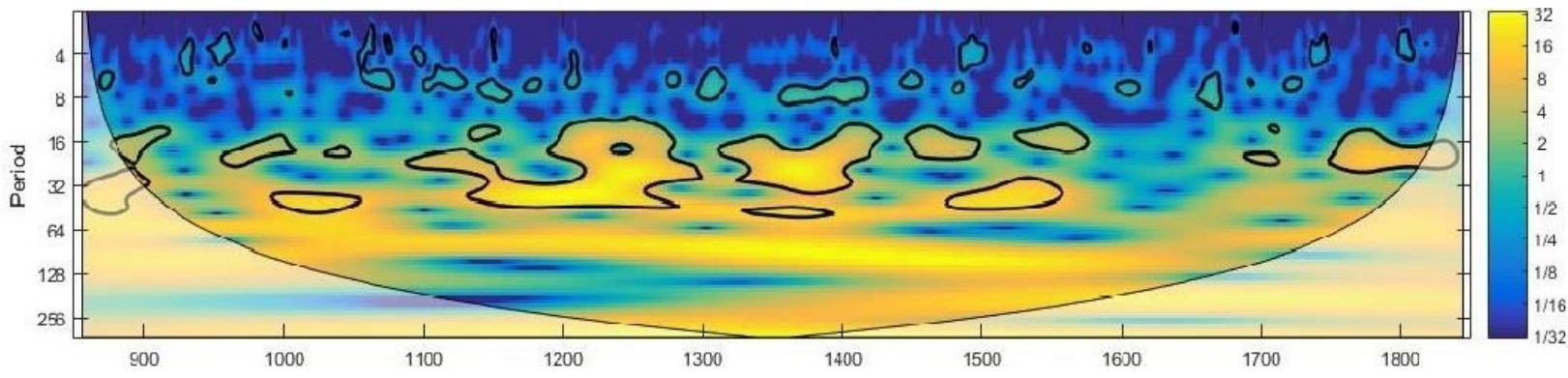

b

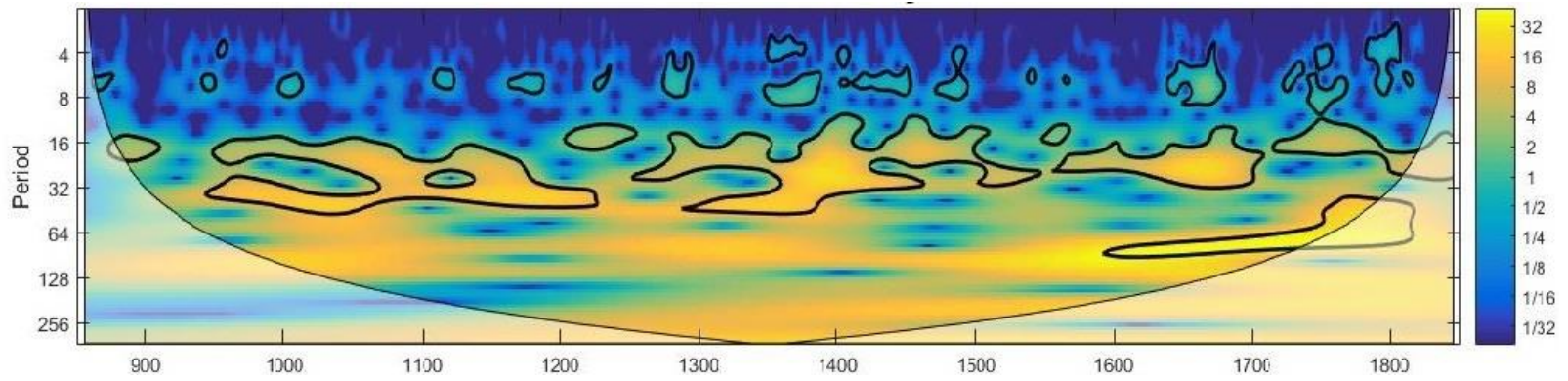

FIG. 5. Wavelet power spectrum (using the Morlet wavelet) of the area of drought anomaly categorized (a) moderate and (b) severe \& extreme drought. The wavelet power is normalized by the global wavelet spectrum. The thick black contour designates the $5 \%$ significance level against red noise and the cone of influence (COI) where edge effects might distort the picture is shown as a lighter shade.

ENSO is considered to contribute directly to the dry/wet conditions over the Maritime Continent (Robertson et al. 2011). The ENSO index is reconstructed as the leading mode in empirical orthogonal function (EOF) of the SST from the HadCM3 model output in the tropical Pacific waters region along the coordinates of $20^{\circ} \mathrm{N}-20^{\circ} \mathrm{S}$ and $120^{\circ} \mathrm{E}$ $66^{\circ} \mathrm{W}$, which is reduced to the annual climatological cycles and average monthly SST over the data period (Newman et al. 2003). The time series of ENSO reconstruction index is shown in Fig. 6a. The reconstructed ENSO pattern on the Last Millennium (Fig. 6b) shows no significant difference with the recent spatial pattern of ENSO as investigated by Wang et al. (2016). Using the CWT (Fig. 6c), it is found that ENSO in the Last Millennium has the dominant mode on the interdecadal time scale. In recent conditions, the region experiences dry/wet conditions due to ENSO also experiencing dry/wet conditions modulation in the event of a phase similarity between PDO and ENSO (Wang et al. 2014). Thus, in this discussion, we also used the reconstructed PDO index from the HadCM3 output (Fig. 7a) by performing the leading mode in EOF calculation of SST in the North Pacific above $20^{\circ} \mathrm{N}$ (Mantua 2002). The PDO spatial pattern derived from the HadCM3 Last Millennium simulation output (Fig. 7b) has no significant difference compared to recent PDO spatial pattern as observed by Mantua (2002) and Newman et al. (2016). By performing the CWT, this reconstructed PDO shows the dominant mode on a multidecadal time scale (32 - 64 year cycle) in the ca. $900-1000 \mathrm{CE}$, and in ca. 1400 - 1700 CE PDO's have two dominant modes, the bidecadal mode (16 32 year cycle) and centennial mode (128 256 years), while post-1800s CE is actually the dominant mode of PDO occurs in the periodicity of 32 - 64 year cycle (Fig. 7c).

By applying cross-correlations between the ENSO index and the PDO (Fig. 8), we have statistical correlations between these two phenomena. The cross-correlation coefficient between PDO and ENSO in the Last Millennium of the HadCM3 output (0.4302) has little difference with the crosscorrelation coefficients between ENSO and PDO obtained through proxy data reconstruction by Huang et al. (2010) of 0.39 . This statistical result indicates a trend of phase similarity between PDO - ENSO in the Last Millennium, which also occurs in the 
recent condition and has been studied by Allan et al. (2003).

a

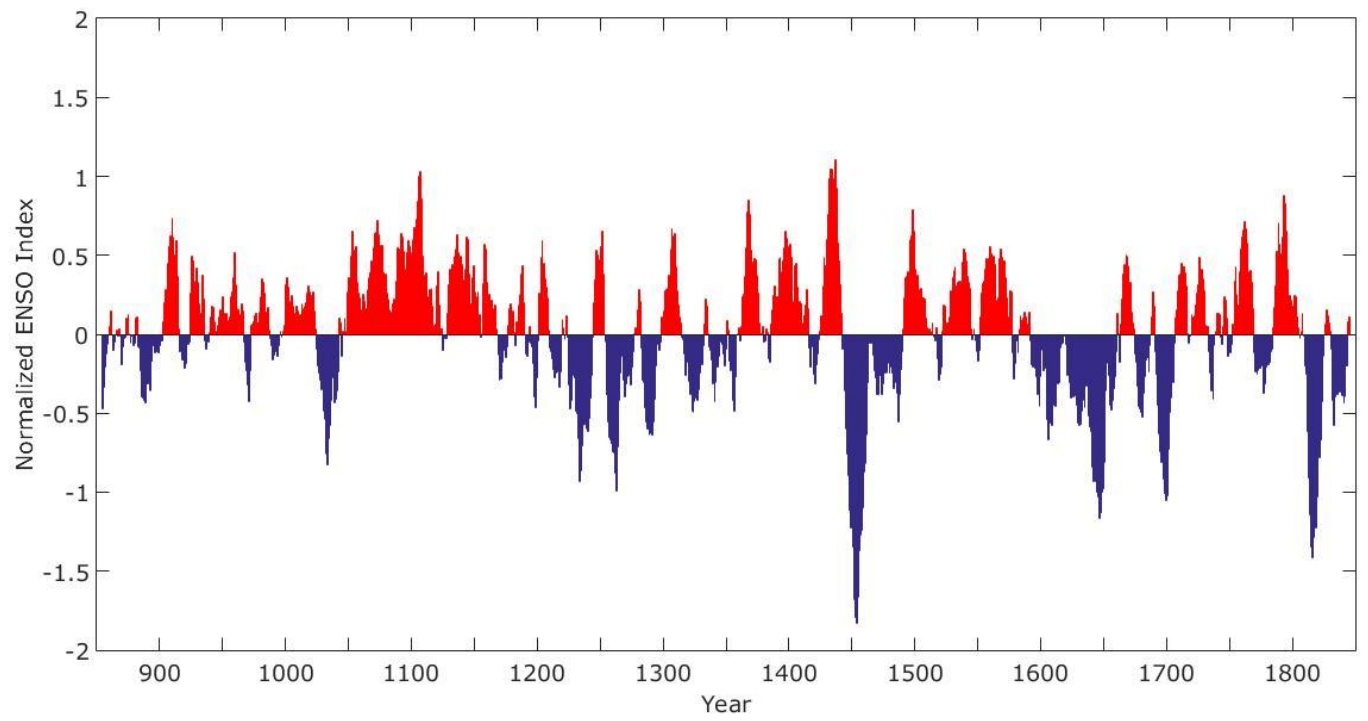

b

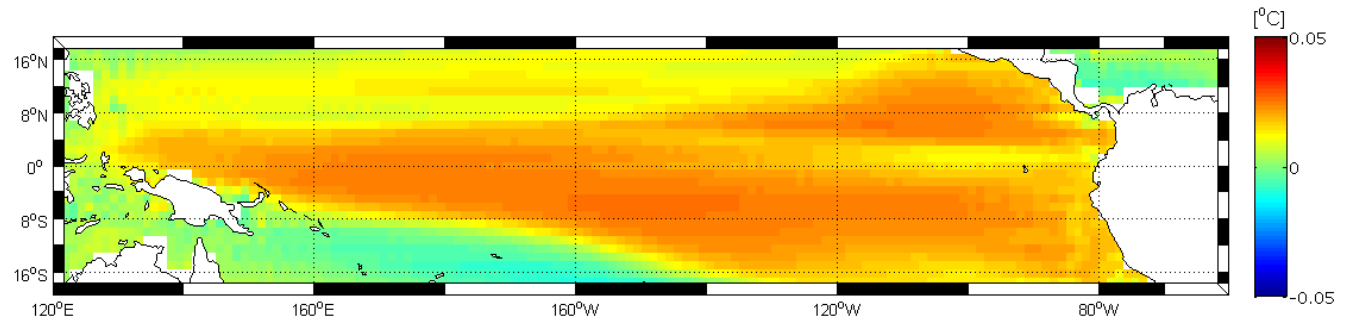

C

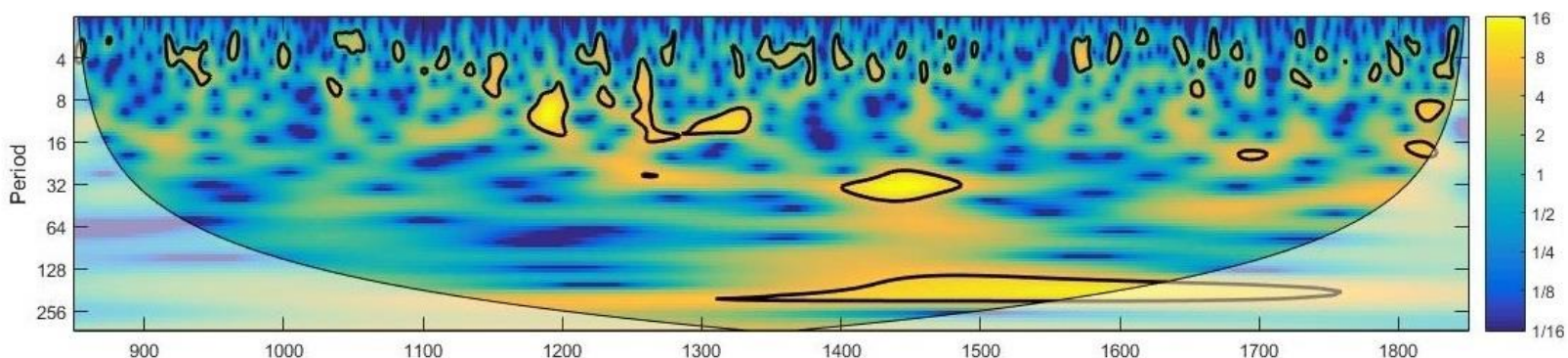

FIG. 6. (a) The normalized ENSO time series in the Last Millennium, this result was calculated using leading modes (EOF) in the tropical Pacific region along the coordinates of $20^{\circ} \mathrm{N}-20^{\circ} \mathrm{S}$ and $120^{\circ} \mathrm{E}-66^{\circ} \mathrm{W}$ from $\mathrm{HadCM} 3$ 
r1i1p1 Last Millennium simulation; (b) first mode of singular value decomposition of SST in the tropical Pacific , showing the spatial patterns of ENSO. (c) Wavelet power spectrum (using the Morlet wavelet) of the reconstructed Last Millennium ENSO index. The wavelet power is normalized by the global wavelet spectrum. The thick black contour designates the 5\% significance level against red noise and the cone of influence (COI) where edge effects might distort the picture is shown as a lighter shade.

a

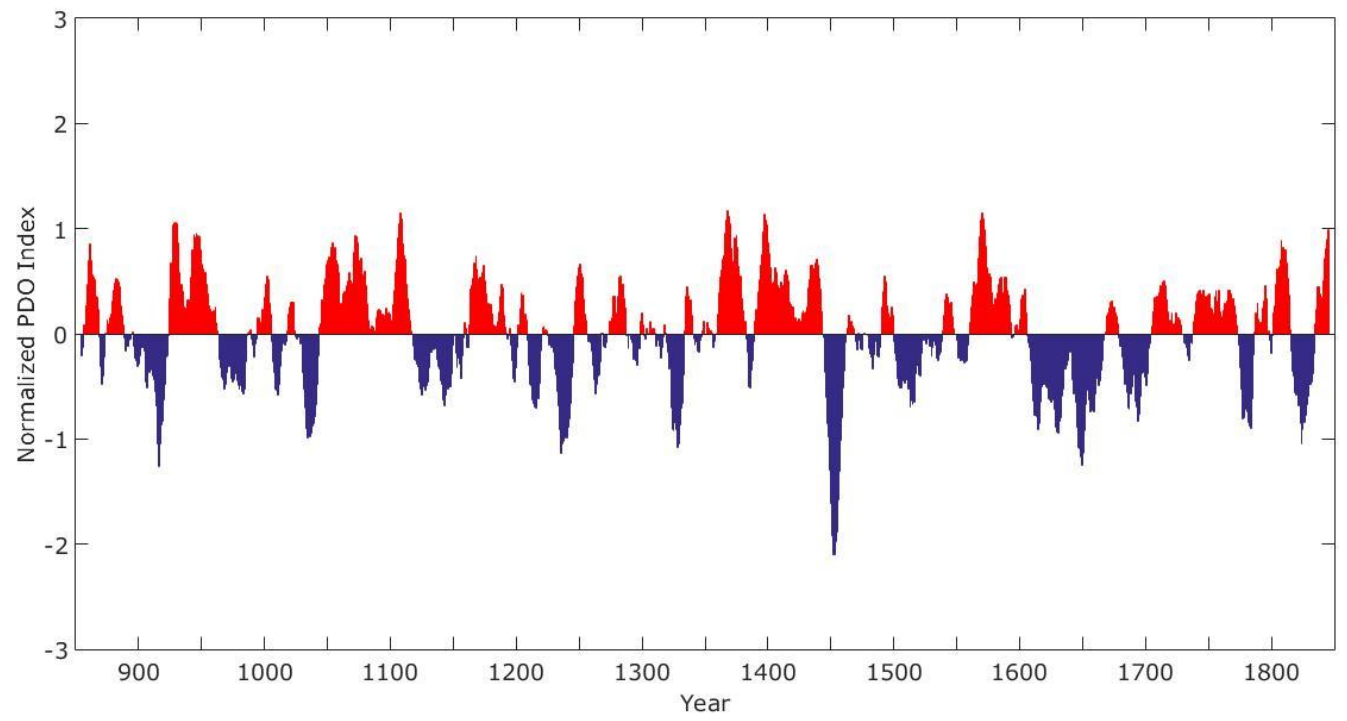

b

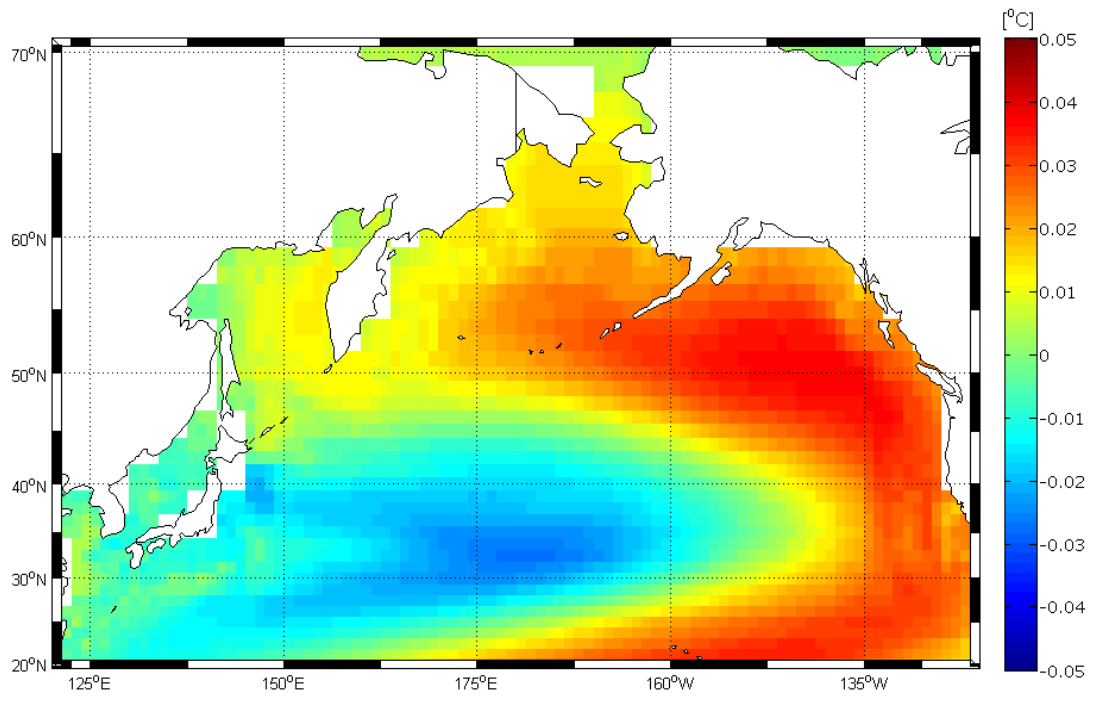




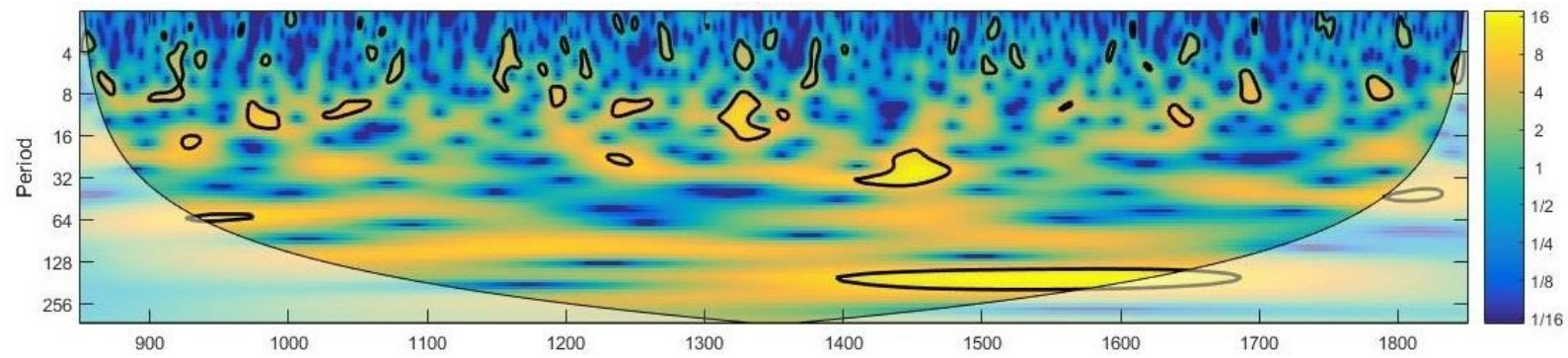

FIG. 7. (a) The normalized PDO time series in the Last Millennium, this result was calculated using leading modes (EOF) in the North Pacific above $20^{\circ} \mathrm{N}$ (Mantua 2002) from HadCM3 r1i1p1 Last Millennium simulation; (b) first mode of singular value decomposition of SST in the North Pacific, showing the spatial patterns of PDO. (c) Wavelet power spectrum (using the Morlet wavelet) of the reconstructed Last Millennium PDO index. The wavelet power is normalized by the global wavelet spectrum. The thick black contour designates the $5 \%$ significance level against red noise and the cone of influence (COI) where edge effects might distort the picture is shown as a lighter shade.

Statistically, there is a resemblance to the dominant mode between the PDO and the anomalous area of drought over the Maritime Continent in the Last Millennium (Fig. 5 and Fig. 7c). The coherence between the PDO index and the anomalous area of drought over the Maritime Continent which calculated through wavelet coherence (Grinsted et al. 2004) is shown in Fig. 9. It is statistically known that there is strong coherence, where the PDO in-phase and precedes the anomalous area of the drought with the periodicity of 128 - 256 years in most of the data period. While in the quasi-centennial period (64 - 128 year cycle) PDO is also inphase and precedes the anomalous extent of drought in the year ca.1500-1800 CE. In order to assure the relationship between PDO - ENSO against drought events over the Maritime Continent, we analyze spatial DJF composites from SPI-12 against the ENSO-PDO phase. Assuming the condition of Last Millennium is not much different from the recent condition, the SPI-12 that used is SPI-12 at the time of boreal winter (DJF) which most shows teleconnection between PDO and ENSO (Newman et al. 2003; Wang et al. 2014). Based on the spatial analysis (Fig. 10), it is known that El Niño-induced drought changes are magnified in most of the Maritime Continent region when in-phase with the PDO warm phase, this is in accordance with the recent PDO - ENSO composite teleconnections with the selfcalibrated Palmer Drought Severity Index (sc_PDSI) calculation (Wang et al. 2014). The influence of other ENSO and PDO phases on dry/wet conditions over the Maritime Continent can be seen in DR3. 


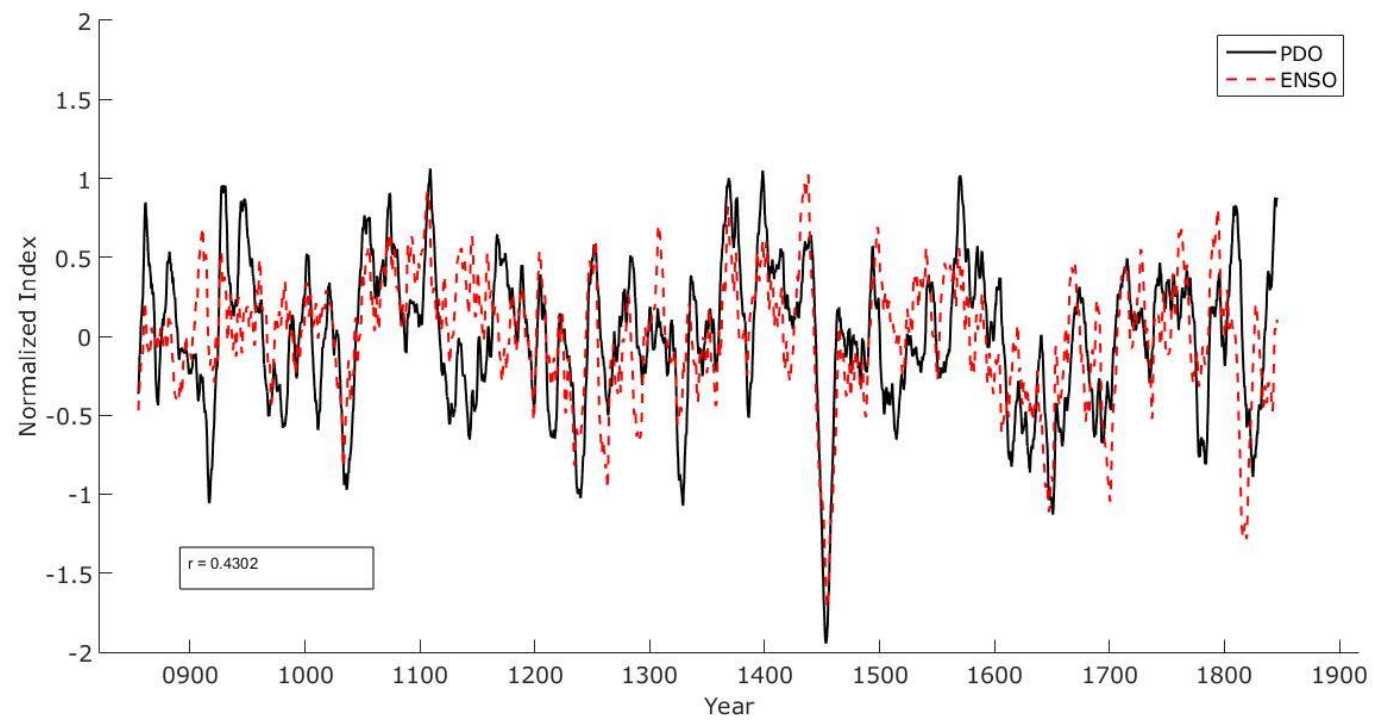

FIG. 8. The comparison of PDO index with ENSO displayed by cross-correlation coefficient (0.4302) in HadCM3 output in Last Millennium shows no significant difference with cross-correlation proxy-based (0.39) in JianBin et al. (2010).

The influence of drought on the sociopolitical dynamics in Southeast Asia in the Last Millennium was obtained by observing the frequency of drought occurrence anomalies and time series anomalous area of drought data over the Maritime Continent, so we obtained time periods and in certain areas in Southeast Asia which experienced the worst drought anomalies. The results of this descriptive assessment are then used as a basis for matching with secondary historical sources to determine the sociopolitical impact on the dynamics of the social life of Southeast Asians in the Last Millennium.

Looking at the political structure of Southeast Asia in Last Millennium certainly can not use the institutional history approach that is generally used as a basis for conducting preliminary studies in political history (Kuntowijoyo 2003). Because of the relatively loose nature of Southeast Asian political structures prior to the reinforcement of the colonial government system in the early 20th century, Ricklefs et al. (2013) termed it as a mandala structure, where interpersonal relationships were primarily used in supporting the system of government, a more diachronic (extending) political historical analysis to other social fields first mentioned in the journal Annales d'histoire économique et sociale by French historians in the early 20th century (Kuntowijoyo 2003). In general, we have come to know that the worst period of drought in the Maritime Continent of the Last Millennium occurred in the period 1350 1451 and 1751 - 1850 CE (Fig.2; Fig. 3; DR2). The periods of 1350 - 1451 CE are marked by decline, even the collapse of some of the glorious countries in the classic Southeast Asian period (ca. 800 - $1300 \mathrm{CE}$ ) (Ricklefs et al. 2013). 

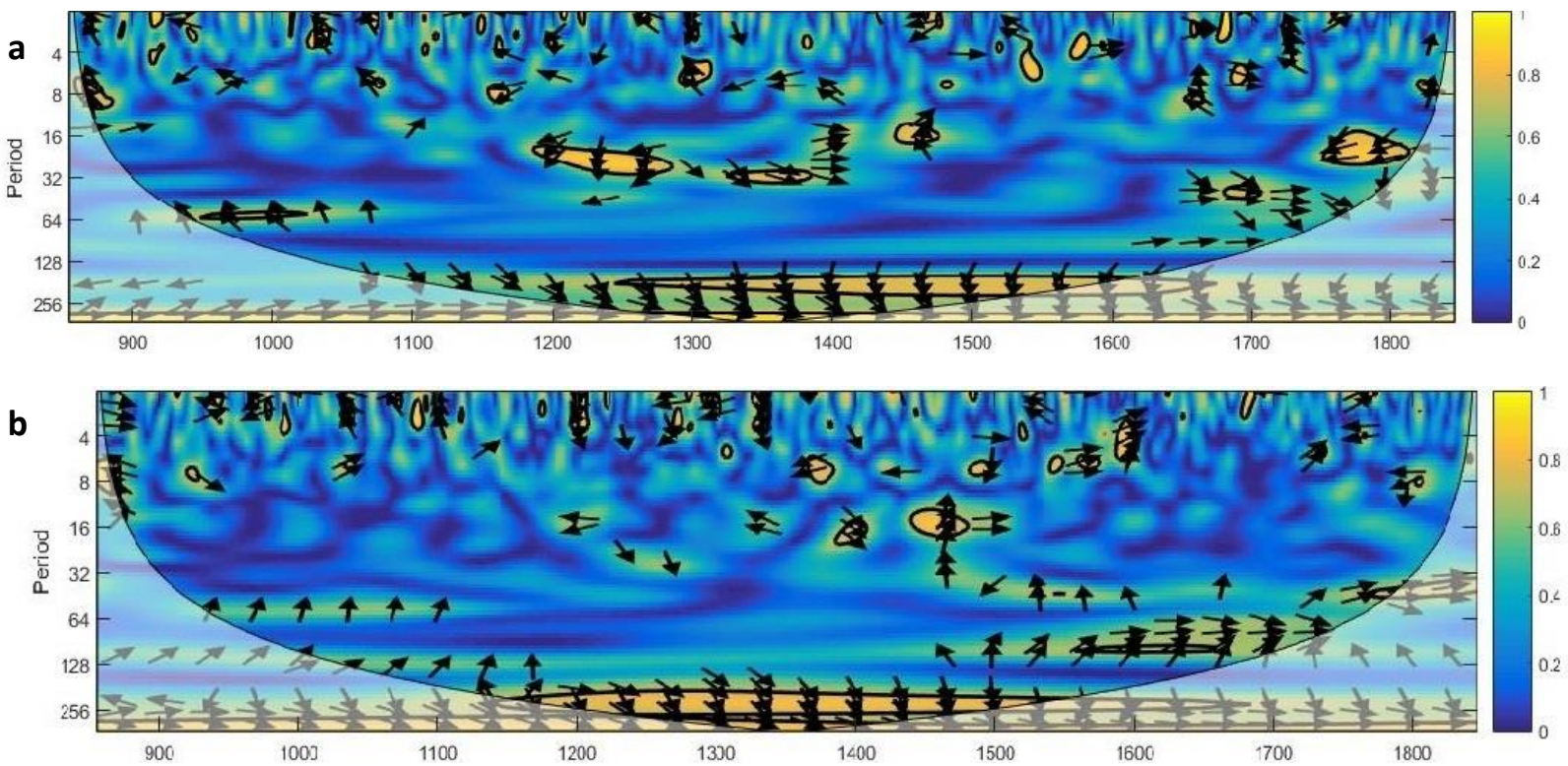

FIG. 9. Wavelet coherence of PDO index with area of drought anomaly, categorized: (a) moderate and (b) severe \& extreme drought over the Last Millennium period. The arrows show the phasing direction, the colored contours show the magnitude of the coherence, and the black outline shows significance at the $95 \%$ level. Shaded regions are outside the significance windows.

Northern Vietnam which had been independent from the Chinese Empire for approximately 400 years (since $1009 \mathrm{CE}$ ) experienced a brief re-enactment by the Ming Dynasty of China (1407 - 1427 CE) preceded by a civil war between the Tran Dynasty and the Ho Dynasty. This civil war was probably also triggered by the distrust of officials of Ho Quy Ly -founder of the Ho Dynasty- against the Tranh Dynasty as a consequence of the Champa's invasion of several areas in Tonkin (North Vietnam) between 1361 and 1390 CE (Buckley et al. 2014; Ricklefs et al. 2013). In the period 1351 - $1450 \mathrm{CE}$, there were two major famines in North Vietnam in $1392-1393$ and 1437 CE (Buckley et al. 2014). Ming Emperor's ambition, Yongle (1402 - 1424 $\mathrm{CE}$ ) to take control of North Vietnam seems to be bumping into drought conditions in some areas of South China (Yunnan) itself. With the tenacity of Vietnam's Le Loi nationalist rebel based in Lam Son, Thanh
Hoa Province, coupled with domestic instability due to drought and famine, Ming's troops were finally withdrawn from Tonkin by the end of 1427 CE (Buckley et al. 2014; Ricklefs et al. 2013). Meanwhile, the southern part of Vietnam which was part of the territory of the sovereignty of the kingdoms of Champa was relatively less affected by this severe drought. With the Annamite Mountains playing a natural defense role, the territory of the Champa kingdoms has a more dominant local climate variability (Buckley et al. 2014). The Champa kingdoms also have other advantages, namely the non-densely populated population and natural forests around Bien Hoa that serve as a catchment area (Buckley et al. 2014). This advantage made Champa capable of expanding northward in this period, and also able to repeatedly threaten the Angkor region that was weak due to drought disaster, eventually controlling one of Angkor region around Dong Nai River in north Saigon (Vickery 2011 in Buckley et al. 2014). 
a

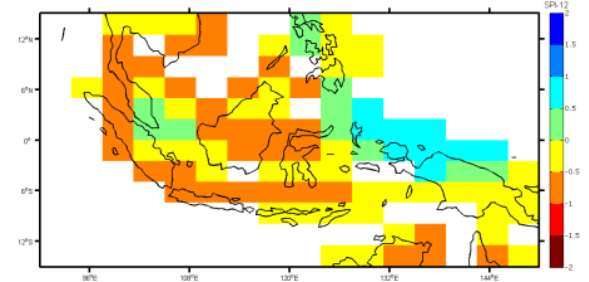

b

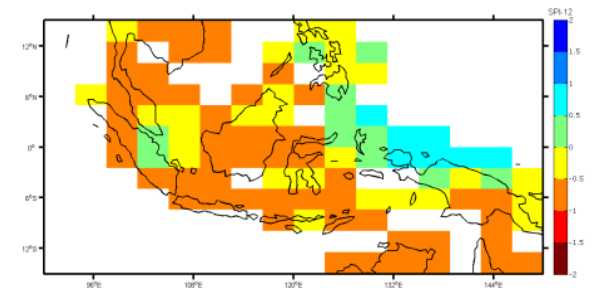

FIG. 10. Composites of the DJF detrended monthly SPI-12 over the Maritime Continent for the Last Millennium period. (a) EI Niño, (b) El Niño-warm PDO. The stippling indicates a $90 \%$ confidence level according to a two-tailed Student's t-test.

The history of the Nusantara in the 14th century until the 15th century was dominated by the two major kingdoms, Majapahit in Java Island, and Malacca in the Malay Peninsula (Ricklefs 2008). In terms of religiosity itself, this turn of the century is the initial stage of Islamic initiation to replace Hindus - Buddhists who previously dominated the Nusantara. There is a difference of political perspective between Malacca and Majapahit in economic terms. Majapahit, though well known as a maritime kingdom, but Majapahit's focus remains as an agrarian kingdom -hanging fate on agricultural hydrological systems-, as most other later Javanese kingdoms (Ricklefs 2008). As for Malacca as other kingdoms in Sumatra, it is more maritime by relying on trade rather than agriculture (Ricklefs 2008). The perspective of a country in economic activity certainly affects the response of political conditions in the event of drought.

Majapahit which at the beginning of the 14th century reached its heyday, suffered a decline of civilization in this period. The civil war of 1405-1406 CE, the succession of the imperial conflicts of the 1450 s CE, and the great revolt of one of the nobles in $1468 \mathrm{CE}$ precipitated the fall of Majapahit into the hands of Demak Islam -more trade-mindedin 1478 CE (Ricklefs 2008). The lack of reliable historical records and the absence of archaeological research on Majapahit hydrological sites makes the argument of long drought as one of the causes of the Majapahit collapse has not had a solid foundation. Further archaeological research is required, especially on the remaining three reservoirs (Domas, Kumitir, and Baureno) and many other waterways made of bricks in Kotaraja Majapahit, Trowulan.
The weakening of the Majapahit empire in the archipelago followed by the rise of Malacca at the end of the 14th century, to the beginning of the 15th century (Ricklefs 2008). A prince named Parameswara who managed to escape from Majapahit invasion to Palembang in 1377 CE. Parameswara after adopting the title of Sultan Iskandar Shah- made a treaty with orang laut who were pirates roaming the Straits of Malacca to force merchant ships to harbor in Malacca (Ricklefs 2008). Malacca managed to widen its influence as a trading hub in the Nusantara until the Portuguese conquered it in 1511 CE (Ricklefs et al. 2013). The economic nature of Malacca, which relies on maritime trade, makes the impact of drought not so much affect the political condition of this kingdom, although further research is needed.

The impact of severe drought in the 1351 1450 CE period that has been extensively studied is the decline of the Angkor Kingdom after the death of Jayavarman VII (Ricklefs et al. 2013). As an agrarian kingdom, Angkor built a fairly good irrigation system by relying on large reservoirs, called baray, scattered in the core areas of the kingdom (Ricklefs et al. 2013). Allegedly after the death of Jayavarman VII, most of the baray was damaged and unkempt, so in the face of severe drought, Angkor residents were not ready (Buckley et al. 2010; Ricklefs et al. 2013). Then, since the 15th century, there was a periodic war between Angkor and the new power of Southeast Asia's mainland, Ayutthaya. Most of Angkor's territory was finally able to be captured by Ayutthaya, until finally the succession of the capital moved to Lovek, Oudong, and finally in Phnom Penh (Ricklefs et al. 2013). The displacement of the capital is also thought to be the royal government's response to the drought, as 
with the removal of the capital to Phnom Penh -by the Mekong and Tonle Sap Rivers-, the new Cambodian kingdom hopes to engage in maritime commerce -changing the economic perspective of the agrarian kingdom into a maritime kingdom- which at the time was bustling because of the maritime expeditions conducted by the Ming Dynasty (Buckley et al. 2010; Ricklefs et al. 2013). Nonetheless, Cambodia is difficult to enter the maritime trade scene, due to less promising produce and its less strategic position (Buckley et al. 2010). Cambodia could not fully rise to the glory of Angkor, to the colonization of France by the end of the 19th century, the kingdom of Cambodia is in the shadow of the two great powers in the Southeast Asian mainland region of Vietnam and Siam (Ricklefs et al. 2013).

The worst episode of drought over the Maritime Continent on Last Millennium either temporally or spatially occurred in 1751$1850 \mathrm{CE}$. The late 18th century until the mid19th century was also recorded as a period of turmoil in South Asia, Southeast Asia, and even to reach North Asia (Kahan 1985; Liebermann 2003 in Buckley et al. 2014). This drought episode also recorded an impact on hunger and chaos in South India and Sri Lanka (Cook et al. 2010).

The Vietnam region after the brief occupation of the Ming Dynasty was divided into two parts, North and South. The Le/Trinh regime governs the northern region (Tonkin) and the Nguyen regime in the south -Cochin China, including the territories formerly the territory of the Champa kingdoms-. As a result of the management of these two kingdoms is bad, resulting in social gaps and hunger everywhere, exacerbated by drought events, the Tay Son rebellion lasted for 30 years (1771 - 1802 CE) (Ricklefs et al. 2013). At the end of the 18th century, the Catholic missionaries in Tonkin also noted that in 1770, $1778-1779$, and $1785-1786$ CE there was a famine due to drought and prolonged wars (Forest 1998 in Buckley et al. 2014). The historical record of the Nguyen Dynasty in South Vietnam also noted that Binh Thuan Province, which is in 1794 1798 CE was a territory controlled by Tay Son rebels, had been abandoned by almost all of its civilians due to crop failure due to drought (Buckley et al. 2014). By the time
Nguyen Anh defeated the Tay Son rebels in 1801 CE also recorded drought was engulfing the region of Central Vietnam (Buckley et al. 2014).

A French adventurer named Turpin reports that the severe drought and famine that hit Ayutthaya occurred at the beginning of the 18th century, however, he did not specify exactly the year of the incident (Buckley et al. 2014). Burma, which developed an expansionary military doctrine in the era of the Konbaung government, surrounded the capital of Ayutthaya with a force of 350,000 in $1767 \mathrm{CE}$, was forced to withdraw its troops because there was no logistical boost to feed a large army in the drought (Buckley et al. 2014; Ricklefs et al. 2013). Nevertheless, the bursts of Burmese forces and prolonged drought contributed to Ayutthaya's collapse that had ruled Siam for four centuries in 1767 CE (Ricklefs et al. 2013). Narrated also, when the new Siamese king, Thaksin wants to consolidate Ayutthaya's rule by retaking the city of Chiang Mai, he and his troops find that the city has been dormant due to drought and famine (Buckley et al., 2014). Although there is no written source telling about the drought in Cambodia in the early 19th century, the drought triggered the biggest violent incidents and riots in Cambodian history -even said to be The Dark Ages of Cambodia by David Chandler (Ricklefs et al. 2013) - in the period 1811 1847 CE. The darkest period in Cambodia's history before the 1970s CE was marked by the Vietnam-Siam war in Cambodia. Although Cambodia regained peace under King Duang's rule, Cambodia remained in the shadow of Vietnam-Siamese influence until the French colonial period at the end of the 19th century (Ricklefs et al. 2013).

In the Nusantara itself, especially in Java Island in the mid-19th century, occurred Java War led by Prince Diponegoro.The greatest war between the Dutch East Indies government against the Javanese took place between 1825 and 1830 CE (Ricklefs 2008). The Java War was triggered by the spirit of the new era of European rulers -brought by Daendles and Raffles in the early 19th century - that impressed antifeodalism and interfered in the affairs of the native royal palaces (Ricklefs 2008). Cholera and crop failure due to prolonged drought in the 1820s 
CE made the Javanese who were already humiliated by their traditions interfered with by the West, waged a massive uprising (Ricklefs 2008). This great war ended with the capture of Diponegoro in Magelang in 1830 CE. Cholera, dysentery, malaria, and drought-induced famine resulted in a large number of casualties, accounting for about 15,000 inhabitants from the colonial side and 200,000 from the dead Javanese people (Ricklefs et al. 2013). This costly Java War also contributed to the implementation of the forced cultivation system in Java that lasted until the early 20th century (Ricklefs 2008).

\section{Conclusion}

The variation of temporal drought over the Maritime Continent of the Last Millennium is dominated by the quasi-centennial to centennial dominant mode coherent with the PDO mode, which strengthened in the period ca. 1100 - 1700 CE. PDO precedes drought with phase differences indicating there is a time lag between PDO and area of drought over the Maritime Continent. The spatial drought variation over the Maritime Continent on Last Millennium due to ENSO is amplified by PDO on boreal winter.

Based on the assessment of the frequency of drought occurrence and area of drought anomalies, qualitatively the drought over the Maritime Continent of the Last Millennium period experienced maximum conditions in the mid-14th century until the end of the 15th century -the period with the longest drought area-, and at the beginning of the 17th century until the middle of the century the 19th -period with the most drought area-. The drought over the Maritime Continent of that period was recorded in the political history of Southeast Asian societies, especially in agrarian societies which were then characterized by riots and rebellions due to crop failures and illness.

Acknowledgments. The authors wish to thank Faiz Rohman Fajary, Mila Ghani Kurniati, and Ferio Brahmana for helpful comments that significantly improved this paper. This work was supported by the Weather and Climate Prediction Laboratory ITB, PT Monica Hijau Lestari, PT Mitra Pajakku, and Eco Learning Camp Foundation.

\section{REFERENCES}

Buckley, B. M., K. J. Anchukaitis, D. Penny, E. R. Cook, M. Sano, L. C. Nam, A. Wichienkeeo, T. T. Minh, and T. M. Hong, 2010: Climate as contributing factor in the demise of Angkor, Cambodia. Proc. Natl. Acad. Sci. U.S.A., 107, 6748 - 6752. doi: 10.1073/pnas.0910827107

R. Fletcher, S. Y. S. Wang, B. Zottoli, and C. Pottier, 2014: Monsoon extremes and society over the past millennium on mainland Southeast Asia. Quat. Sci. Rev., 95, 1 - 19. https://doi.org/10.1016/j.quascirev.2014.04.022

Chang, C. P., , P. A. Harr, J. McBride, and H. H. Hsu, 2004: Maritime Continent monsoon: Annual cycle and boreal winter. East Asian Monsoon, C. P. Chang, Ed., World Scientific Series on Meteorology and East Asia, Vol. 2, World Scientific, 107-150. https://doi.org/10.1142/97898127014110003

Clift, P. D., and R. A. Plumb, 2008: The Asian Monsoon Causes, History and Effects. Cambridge University Press, $270 \mathrm{pp}$.

Cook, E. R., K. J. Anchukaitis, B. M. Buckley, R. D. D' Arrigo, G. C. Jacoby, and W. E. Wright, 2010: Asian Monsoon Failure and Megadrought During the Last Millennium. Science, 328, 486 - 489. doi: $\underline{10.1126 / \text { science. } 1185188}$

deMenocal, P. B., 2001: Cultural responses to climate change during the late Holocene. Science, 291, 667 - 673. doi: 10.1126/science. 1059287

Dow, G. K., N. Olewiler, and C. G. Reed, 2005: The Transition to Agriculture: Climate Reversals, Population Density, and Technical Change. J. Econ. Hist., 0509003. http://econwpa.repec.org/eps/eh/papers/0509/05090 03.pdf

Fallah, B., and U. Cusbasch, 2015: A comparison of model simulations of Asian mega-droughts during the past millennium with proxy reconstructions. Clim. Past., 11, 253 - 263. https://doi.org/10.5194/cp-11253-2015

Grinsted, A., J. C. Moore, and S. Jevrejeva, 2004: Application of the cross wavelet transform and wavelet coherence to geophysical time series. Nonlinear Process Geophys., 11, 253 - 263. SRefID: 1607-7946/npg/2004-11-561

Gupta, A., 2004: Origin of agriculture and domestification of plants and animals linked to early holocene climate amelioration. Curr. Sci., 87, 54-59. http://www.ias.ac.in/currsci/jul102004/54.pdf

Huang, J. B., S. W. Wang, D. Y. Gong, T. J. Zhou, X. Y. Wen, Z. Y. Zhang, and J. H. Zhu, 2010: Atmospheric oscillations over the last millennium. 
Chin. Sci. Bull., 55, 2469-2472. doi: 10.1007/s11434-010-3210-8

Konecky, B. L., J. M. Russell, J. R. Rodysill, M. Vuille, S. Bijaksana, and Y. Huang, 2013: Intensification of southwestern Indonesian rainfall over the past millennium. Geophys. Res. Lett., 40, 386 - 391. doi: $\underline{10.1029 / 2012 G L 054331}$

Kanamitsu, M., W. Ebisuzaki, J. Woollen, S.-K. Yang, J. J. Hnilo, M. Fiorino, and G. L. Potter, 2002: NCEPDOE AMIP-II Reanalysis (R-2). Bull. Amer. Meteor. Soc., $\quad 83, \quad 1631 \quad$ - 1643. https://doi.org/10.1175/BAMS-83-11-1631

Kuntowijoyo, 2003: Metodologi Sejarah Edisi Kedua [Historical Methodology 2nd Edition]. Tirta Wacana Yogya, $287 \mathrm{pp}$.

Li, J., S. P. Xie, E. R. Cook, M. S. Morales, D. A. Christie, N. C. Johnson, F. Chen, R. D'Arrigo, A. M. Fowler, X. Gou, and K. Fang, 2013: El Niño modulations over the past seven centuries. Nat. Clim. Change, 3, 822 - 826. doi:10.1038/nclimate1936

Mantua, N. J., 2002: Pacific-Decadal Oscillation. The Earth system: physical and chemical dimensions of global environmental change, M. C. MacCracken, and J. S. Perry, Ed., Encyclopedia of Global Environmental Change, Vol. 1, 592 - 594.

McKee, T. B., N. J. Doesken, and J. Kleist, 1993: The relationship of drought frequency and duration of the time scales. 8th Conf. on Applied Climatology, Anaheim, CA, Amer. Meteor. Soc., p. 179 - 184. http://clima1.cptec.inpe.br/ rclima1/pdf/paper spi.pd f

Newman, M., G. P. Compo, and M. A. Alexander, 2003: ENSO-forced variability of the Pacific decadal oscillation. J. Climate,16, 3853-3857. https://doi.org/10.1175/15200442(2003)016<3853:E VOTPD $>2.0 . C O ; 2$

M. A. Alexander, T. R. Ault, K. M. Cobb, C. Deser, E. D. Lorenzo, N. J. Mantua, A. J. Miller, S. Minobe, H. Nakamura, N. Schneider, D. J. Vimont, A S. Phillips, J. D. Scott, and C. A. Smith, 2016: The Pacific Decadal Oscillation, Revisited. J. Climate, 29, 4399 - 4427. https://doi.org/10.1175/JCLI-D-15$\underline{0508.1}$

Newton, A., R. Thunell, and L. Stott, 2006: Climate and hydrographic variability in the Indo-Pacific Warm Pool during the last millennium. Geophys. Res. Lett., 33, L19710. doi: 10.1029/2006GL027234

Ramage, C.S., 1968: Role of a tropical "Maritime Contient" in the atmosphere circulation. Mon. Wea. Rev., 96, 365 - 370. https://doi.org/10.1175/15200493(1968)096<0365:ROATMC>2.0.CO;2

Ricklefs, M. C., 2008: Sejarah Indonesia Modern 1200 - 2008 [A History of Modern Indonesia Since c. 1200 Fourth Edition] (Tim Penerjemah Serambi, Trans.). Serambi, $865 \mathrm{pp}$.
B. Lockhart, A. Lau, P. Reyes, and M. A. Thwin, 2013: Sejarah Asia Tenggara Dari Masa Prasejarah sampai Kontemporer [A New History of Southeast Asia] (Tim Komunitas Bambu, Trans.). Komunitas Bambu, 826 pp.

Robertson, A. W., V. Moron, J. H. Qian, C. P. Chang, F. Tangang, E. Aldrian, and T. Y. Koh, 2011: The Maritime Continet monsoon. The Global Monsoon System: Research and Forecast 2nd edition, C.P. Chang et al., Ed., World Scientific Series on AsiaPacific Weather and Climate, Vol. 5, World Scientific, 85 $-$ 98. https://doi.org/10.1142/9789814343411 0006

Rodysill, J. R., J. M. Russell, S. Bijaksana, E. T. Brown, L. O. Safiuddin, and H. Eggermont, 2012: A paleolimnological record of rainfall and drought from East Java, Indonesia during last 1,400 years. J. Paleolimnol., $\quad 47, \quad 125 \quad-\quad 139$. https://doi.org/10.1007/s10933-011-9564-3

Schurer, A. P., G. C. Hegerl, M. E. Mann, S. F. B. Tett, and S. J.Phipps, 2013: Separating forced from chaotic climate variability over the past millennium. J. Climate, 26, 6954-6973. https://doi.org/10.1175/JCLI-D-12-00826.1

Shen, C., W. C. Wang, W. Gong, and Z, Hao, 2006: A Pacific Decadal Oscillation record since 1470 AD reconstructed from proxy data of summer rainfall over eastern China. Geophys. Res. Lett., 33, L03702. doi: 10.1029/2005GL024804

W. C. Wang, Z. Hao, and W. Gong, 2007: Exceptional drought events over eastern China during the last five centuries. Clim. Change, 85, 453 - 471. doi 10.1007/s10584-007-9283-y

Torrence, C., and G. P. Compo, 1998: Practical Guide to Wavelet Analysis. Bull. Amer. Meteor. Soc., 79, 61 - $78 . \quad$ https://doi.org/10.1175/15200477(1998)079<0061:APGTWA>2.0.CO;2

Trenberth, K. E., D. P. Stepaniak, and J. M. Caron, 2000: The Global Monsoon as Seen through the Divergent Atmospheric Circulation, J. Climate, 13, 3969 - 3993. https://doi.org/10.1175/15200442(2000)013<3969:TGMAST>2.0.CO;2

Wang, C., C. Deser, J. Y. Yu, P. DiNezio, and A. Clement, 2016: El Niño and Southern Oscillation (ENSO): A Review. Coral Reefs of the Eastern Pacific, P. Glymn et al.,Springer, 85 - 106. doi 10.1007/978-94-017-7499-4 4

Wang, S., J. Huang, Y. He, and Y. Guan, 2014: Combined effects of the Pacific Decadal Oscillation and El Niño-Southern Oscillation on Global Land Dry-Wet Changes. Sci. Rep., 4, 1 - 8 . doi:10.1038/srep06651

Wardanie, S. P. R., and R. J. Kodoatie, 2008: Disaster Management in Central Java Province, Indonesia, Geotechnical Engineering for Disaster Mitigation and Rehabilitation, Liu H. et al., Ed., 
Springer. https://doi.org/10.1007/978-3-540-79846$\underline{023}$

Wilhite, D. A., 2003: Drought. Encyclopedia of Atmospheric Sciences, J. Holton, Ed., Academic Press, $650-658$.

Yoden, S., S. Otsuka, N. J. Trilaksono, and T. W. Hadi, 2017: Recent Progress in Research on the Maritime Continent Monsoon. Global Monsoon System: Research and Forecast 3rd Edition, C.P. Chang et al., Ed., World Scientific Series on Asia Pacific Weather and Climate, Vol. 9, World Scientific, 63 77.

https://doi.org/10.1142/97898132009130006

Zargar, A., R. Sadiq, B. Naser, F. I. Khan, 2008: A review of drought indices. Environ. Rev., 19, 333 349. https://doi.org/10.1139/a11-013

Zhang, P., H. Cheng, R. L. Edwards, F. Chen, Y. Wang, X. Yang, J. Liu, M. Tan, X. Wang, J. Liu, C.
An, Z. Dai, J. Zhou, D. Zhang, J. Jia, L. Jin, and K. R. Johnson, 2008: A Test of Climate, Sun, and Culture Relationships from an 1810-Year Chinese Cave Record. Science, 322, 940 - 942. doi: $\underline{10.1126 / \text { science. } 1163965}$ 


\section{Supplementary material}



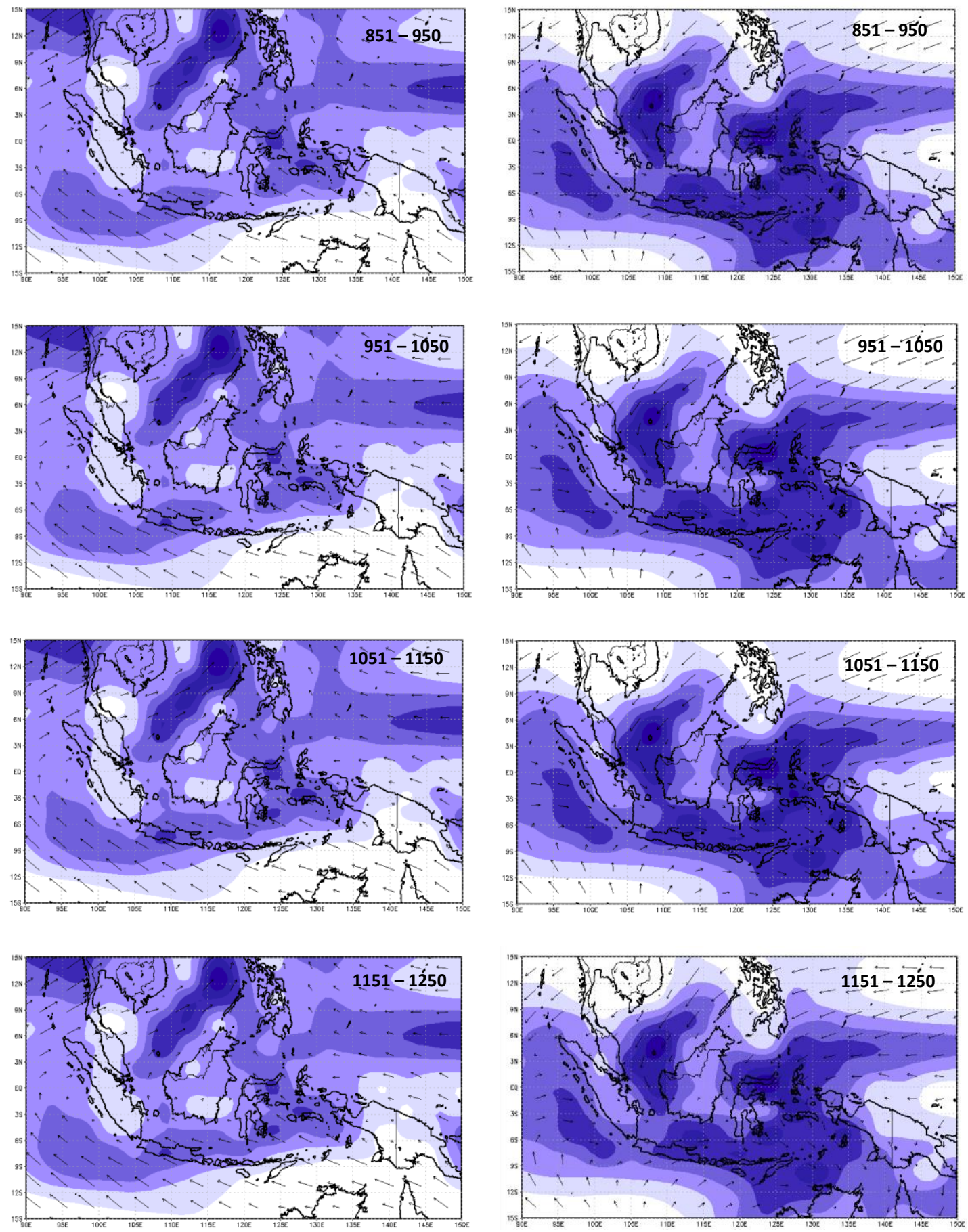

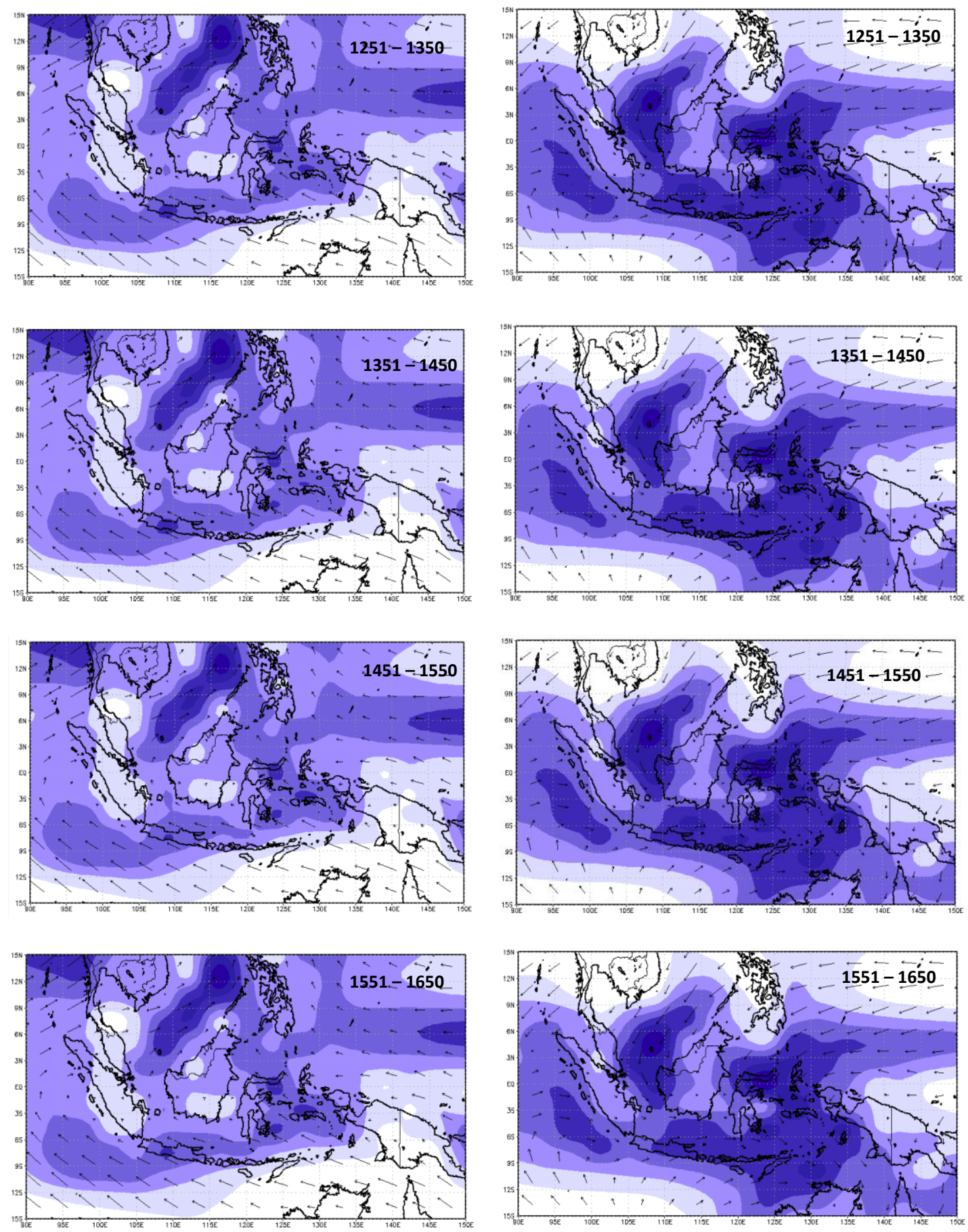

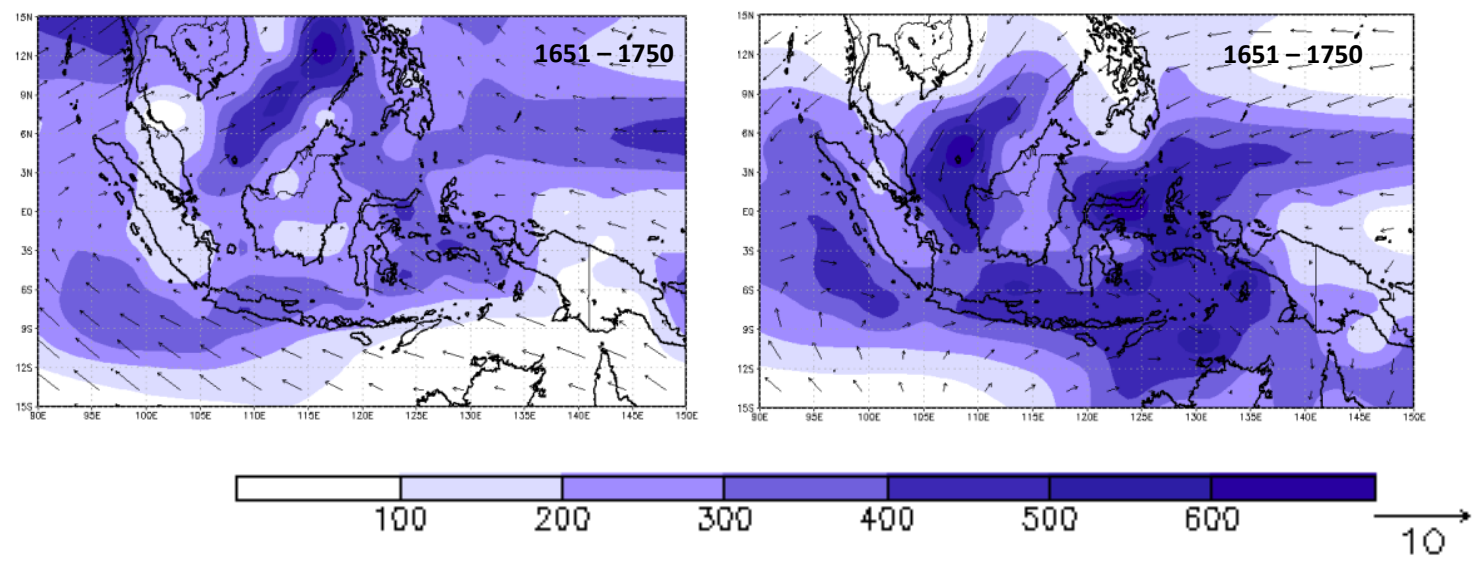

DR1 Contour maps of HadCM3 r1i1p1 Last Millennium simulation for each century in the Last Millennium period, composite means of surface precipitation in mm month-1 with arrows denoting near surface wind direction in $\mathrm{m} \mathrm{s}-1$ for wet season (DJF, left) and dry season (JJA, right)
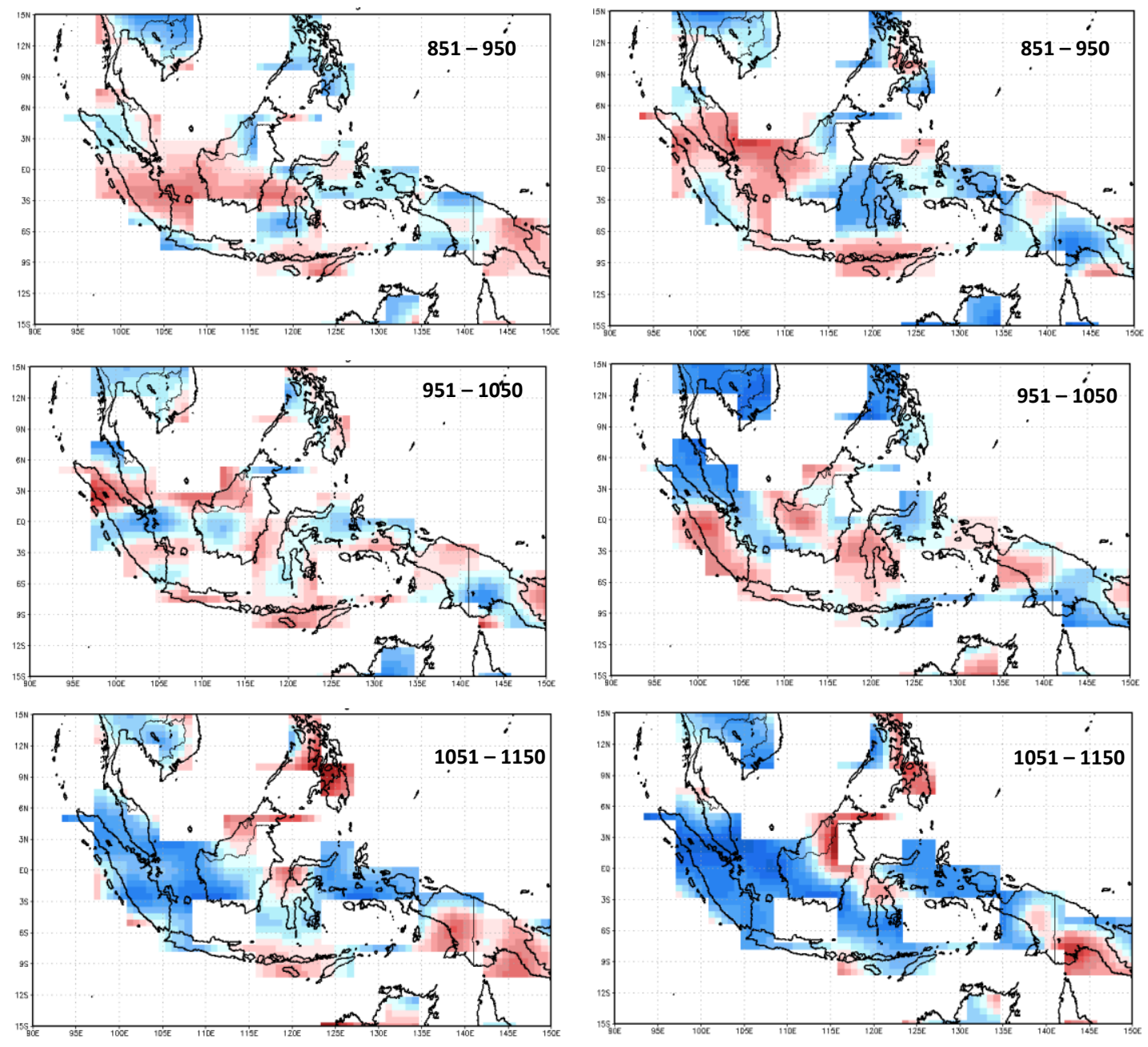

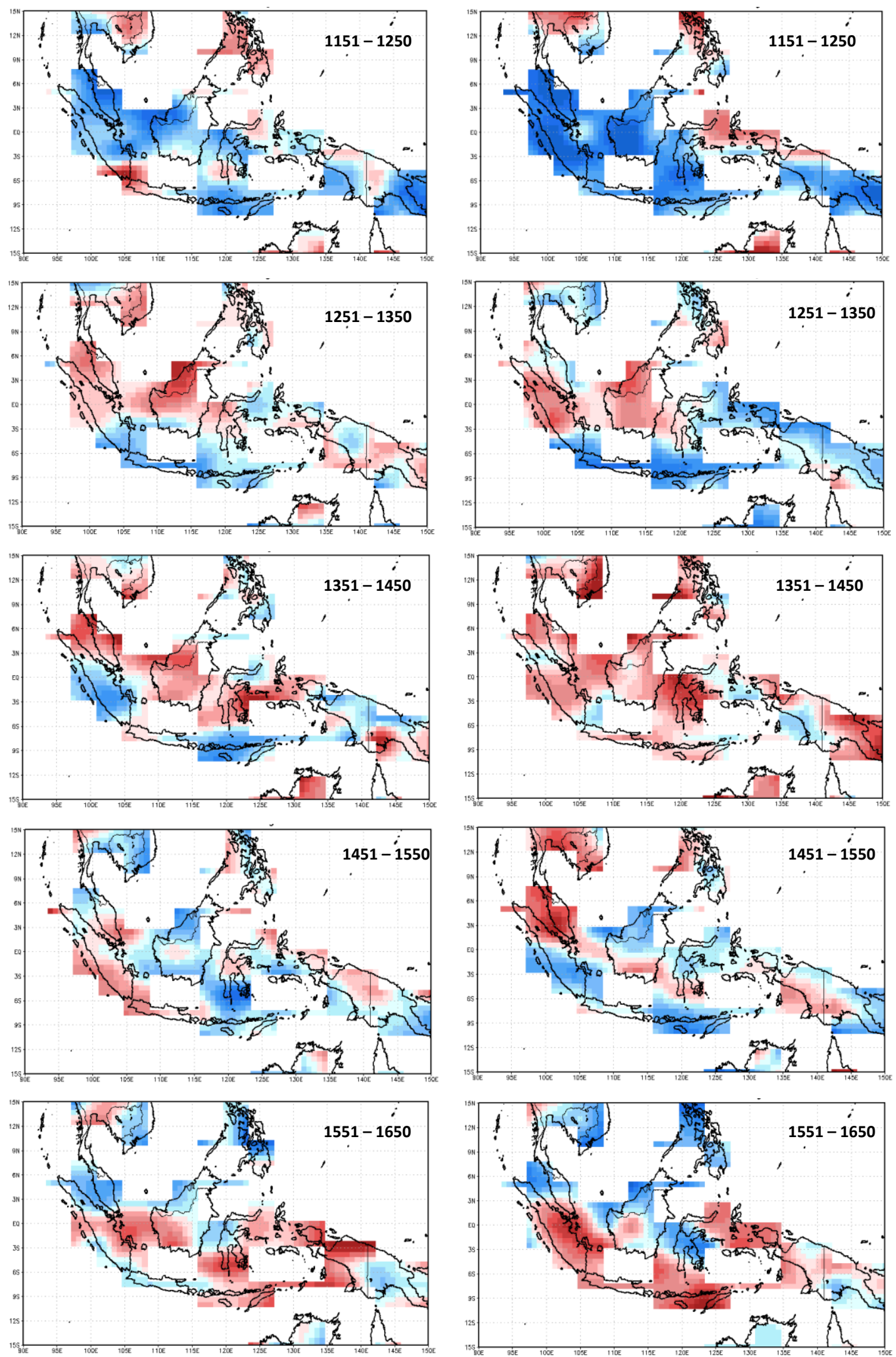

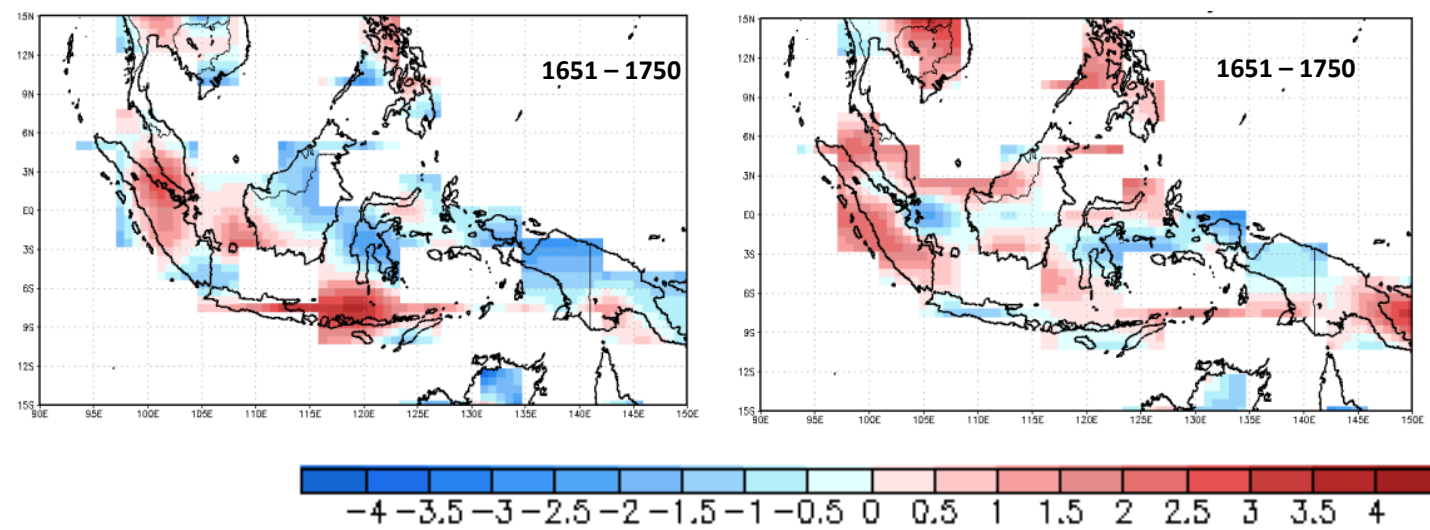

DR2 Drought severity maps categorized moderate (left) and severe \& extreme (right) drought based on the anomaly of meteorological drought frequency of occurrence during the each century in Last Millennium period over the Maritime Continent.
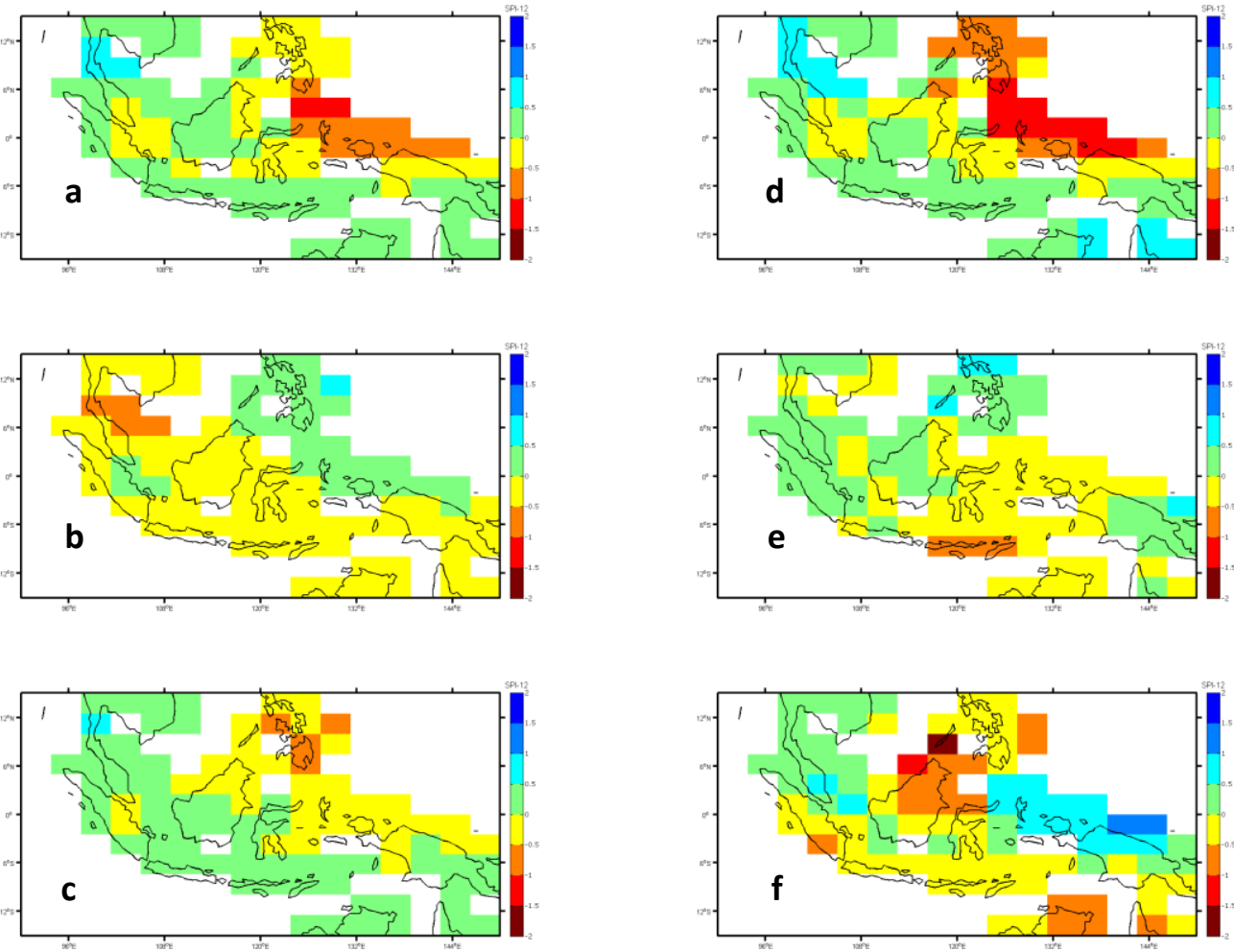

DR3 Composites of the DJF detrended monthly SPI-12 over the Maritime Continent for the Last Millennium period. (a) La Niña, (b) warm PDO, (c) cold PDO, (d) La Niña-cold PDO, (e) La Niñawarm PDO, and (e) El Niño-cold PDO. The stippling indicates a 90\% confidence level according to a two-tailed Student's t-test. 